\title{
CFTR, Mucins, and Mucus Obstruction in Cystic Fibrosis
}

\author{
Silvia M. Kreda ${ }^{1}$, C. William Davis ${ }^{1,2}$, and Mary Callaghan Rose ${ }^{3,4}$ \\ ${ }^{1}$ Cystic Fibrosis/Pulmonary Research and Treatment Center, University of North Carolina, Chapel Hill, \\ North Carolina 27517-7248 \\ ${ }^{2}$ Department of Cell and Molecular Physiology, University of North Carolina, Chapel Hill, \\ North Carolina 27517-7248 \\ ${ }^{3}$ Center for Genetic Medicine Research, Children's National Medical Center, George Washington University \\ School of Medicine and Health Sciences, Washington, D.C. 20010 \\ ${ }^{4}$ Department of Integrative Systems Biology and Department of Pediatrics, George Washington University \\ School of Medicine and Health Sciences, Washington, D.C. 20010 \\ Correspondence: mrose@childrensnational.org
}

Mucus pathology in cystic fibrosis (CF) has been known for as long as the disease has been recognized and is sometimes called mucoviscidosis. The disease is marked by mucus hyperproduction and plugging in many organs, which are usually most fatal in the airways of CF patients, once the problem of meconium ileus at birth is resolved. After the CF gene, CFTR, was cloned and its protein product identified as a cAMP-regulated $\mathrm{Cl}^{-}$ channel, causal mechanisms underlying the strong mucus phenotype of the disease became obscure. Here we focus on mucin genes and polymeric mucin glycoproteins, examining their regulation and potential relationships to a dysfunctional cystic fibrosis transmembrane conductance regulator (CFTR). Detailed examination of CFTR expression in organs and different cell types indicates that changes in CFTR expression do not always correlate with the severity of CF disease or mucus accumulation. Thus, the mucus hyperproduction that typifies CF does not appear to be a direct cause of a defective CFTR but, rather, to be a downstream consequence. In organs like the lung, up-regulation of mucin gene expression by inflammation results from chronic infection; however, in other instances and organs, the inflammation may have a non-infectious origin. The mucus plugging phenotype of the $\beta$-subunit of the epithelial $\mathrm{Na}^{+}$channel $(\beta \mathrm{ENaC}$ )-overexpressing mouse is proving to be an archetypal example of this kind of inflammation, with a dehydrated airway surface/concentrated mucus gel apparently providing the inflammatory stimulus. Data indicate that the luminal $\mathrm{HCO}_{3}^{-}$deficiency recently described for CF epithelia may also provide such a stimulus, perhaps by causing a mal-maturation of mucins as they are released onto luminal surfaces. In any event, the path between CFTR dysfunction and mucus hyperproduction has proven tortuous, and its unraveling continues to offer its own twists and turns, along with fascinating glimpses into biology.

Editors: John R. Riordan, Richard C. Boucher, and Paul M. Quinton

Additional Perspectives on Cystic Fibrosis available at www.perspectivesinmedicine.org

Copyright (C) 2012 Cold Spring Harbor Laboratory Press; all rights reserved; doi: 10.1101/cshperspect.a009589

Cite this article as Cold Spring Harb Perspect Med 2012;2:a009589 
S.M. Kreda et al.

M ucus has long been recognized to reside on the moist, external and internal surfaces of the body. In the early 1930s, for instance, long before he became famous for the codiscovery of penicillin, Howard Florey wrote extensively on mucus secretion in the intestine and airways, as well as on the functions of mucus (Florey 1930; Goldsworthy and Florey 1930; Florey et al. $1932)^{5}$; his observations strike a surprisingly contemporary chord! The concept of mucus as a barrier against harsh environments or pathogens, however, is a more recent concept that was described first for the stomach (Forte and Forte 1970) and the cervix (Enhorning et al. 1970 ) in 1970. Since that time, our appreciation of this barrier function offered by mucus has been refined and generalized (Cone 2009) and is presently being appreciated at the molecular level (Pickles 2004; Linden et al. 2008). Also more recently appreciated is the role that the breakdown of the mucus barrier plays in inflammatory diseases (Rhodes 1989; Knowles and Boucher 2002; Johansson et al. 2010). Studies of the genetic disease cystic fibrosis (CF) have been central to much of our current understanding of the function of the mucus barrier in health and its dysfunction in disease, especially with respect to chronic infection and inflammation of the airways in the lungs of CF patients.

Mucus on most epithelial surfaces, such as airways and ocular surfaces, resides as a single layer of polymeric mucin gel (Hollingsworth and Swanson 2004), a few tens of micrometers thick, overlying the epithelial glycocalyx, which includes a class of mucins tethered to the apical plasma membrane (Hattrup and Gendler 2008; Govindarajan and Gipson 2010). In the stomach and colon, however, there are two layers of mucus, one that is adherent, forms from mucins released by goblet cells, and is impermeable to bacteria. The second is more luminal and non-

\footnotetext{
${ }^{5}$ Many of the manuscripts of Florey and other authors publishing in the 1800s and early 1900s are now available through the archives of PubMed Central, part of the National Library of Medicine. The archive can be searched through PubMed (available at http://www.ncbi.nlm.nih.gov/sites/ entrez), but, because the older references in the PMC database may not be included in the main, PubMed database, one must select the PMC database to access it.
}

adherent, forms from the enzymatic processing of mucins that are continuously released into the adherent layer, and harbors bacteria (Allen et al. 1984; Taylor et al. 2004; Johansson et al. 2011). Under normal conditions, the mucus barrier on epithelia functions as part of the innate immune system; however, under conditions of inflammation, mucus production is accelerated as part of the body's response to infection or other insults, and the resulting hyperproduction can be deleterious to the health of the patient. This phenomenon of mucus hyperproduction and mucus plugging in the airways is especially true for CF patients, as we consider below.

\section{CYSTIC FIBROSIS, MUCUS, AND MUCINS}

\section{Overview}

Cystic fibrosis is often referred to as "mucoviscidosis" in early descriptions of the disease (Farber et al. 1943) because copious amounts of viscid mucus were observed in the gastrointestinal and respiratory tracts of children when the disease was first reported in 1938 (Anderson 1938). Mucus is a viscoelastic material that covers and protects the apical surfaces of the respiratory, gastrointestinal, and reproductive epithelial tracts and is a composite of components secreted apically (luminally) by epithelial and glandular cells in the mucosal epithelium (Rose 2006). Mucin glycoproteins (mucins) are major macromolecular components of lung mucus (Rose et al. 1987; Kesimer et al. 2008). Mucins (MUCs) are heavily O-glycosylated (Fig. 1A,B) and are now identified by the MUC genes that encode their protein backbones. Because these are well described (Rose and Voynow 2006; Thornton et al. 2007; Hattrup and Gendler 2008), they are only briefly reviewed below. The potential involvement in CF of polymeric (Fig. 1A) (Rose 1988; Rose and Voynow 2006) and membrane-tethered mucins (Fig. 1B) (Hattrup and Gendler 2008) has been reviewed. We review more recently published information on mucins and mucin gene regulation and integrate it into our evolving understanding of the contribution of mucins to $\mathrm{CF}$ 

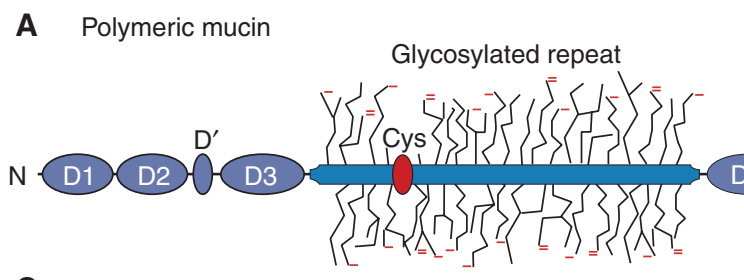

B MUC1
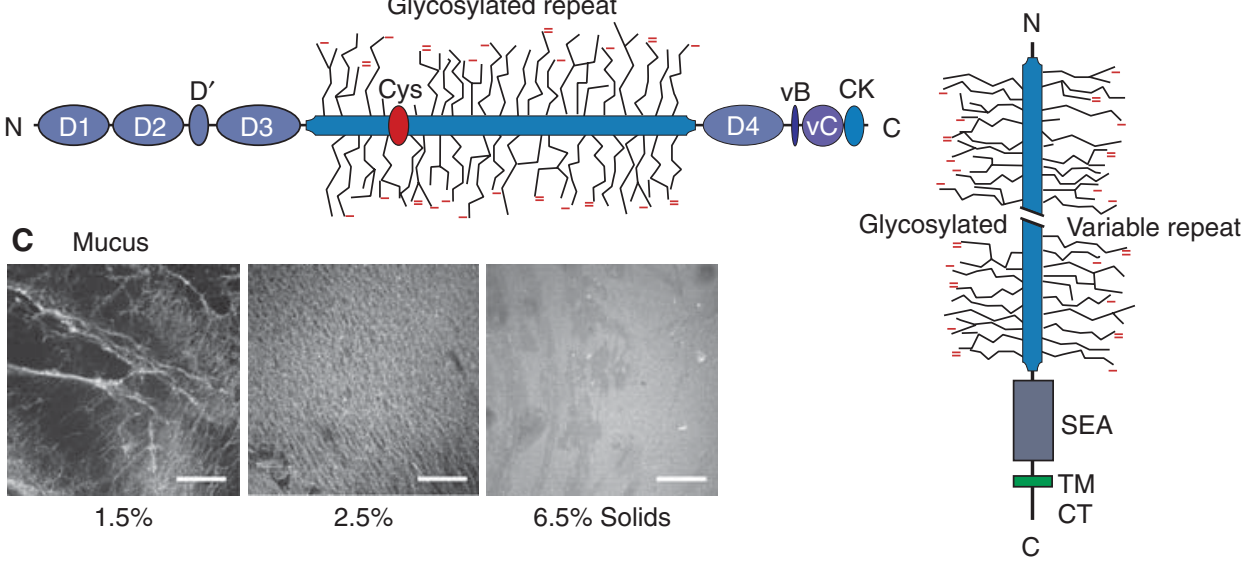

Figure 1. Mucin domain maps and mucus. (A) Domain map for a generic, polymeric mucin (after Fig. 1a in Thornton et al. 2007). Indicated are the vWF vB, vC, and D domains, a Cys-rich domain, and the carboxyterminal cystine knot (CK), in addition to the central glycosylated TR domains. The map most closely represents MUC2; unlike MUC2, MUC5AC and MUC5B have multiple Cys-rich domains within the glycosylated repeat domain (Rose and Voynow 2006). (B) Domain map for a tethered mucin, MUC1 (after Fig. 1A in Hattrup and Gendler 2008). Indicated are the cytoplasmic tail (CT), transmembrane (TM), and SEA domains, as well as the glycosylated TR domains, which for MUC1 can have considerable variation in the number of TRs (Hattrup and Gendler 2008). (C) Mucus harvested from HBE cell cultures, stained with fluorescent wheat germ agglutinin and concentrated to $2.5 \%$ or $6.5 \%$ solids, from a control of $1.5 \%$. The highest concentration ( $6.5 \%$ solids) is representative of CF sputum. (Panel $C$ is from Matsui et al. 2005; reprinted, with express permission, from the author.)

disease, especially with regard to the localization and expression of the cystic fibrosis transmembrane regulator $(C F T R)$ gene, the causative gene of CF disease.

The initial pathology in CF is manifested in mucosal epithelia and represents the basis for the long-standing concept of a fundamental mucus abnormality in CF patients (Fig. 1C). This is supported by ultrasound studies in the gastrointestinal tract, wherein $90 \%$ of CF fetuses manifest inspissated meconium in their distal ileum during the 17-19-wk gestation period (Duchatel et al. 1993). Although this is generally reabsorbed, a small percentage of CF infants present with mucin-containing meconium ileus at birth (Schachter and Dixon 1965). Interestingly, CFTR-null $\left(\mathrm{Cftr}^{-/-}\right)$mice, pigs, and ferrets, that is, gene-targeted animal models that that do not express the Cftr gene, have meconium ileus at birth (Snouwaert et al. 1992; Rogers et al. 2008; Sun et al. 2010; Klymiuk et al. 2011). This mucus overproduction, which reflects markedly increased levels of Muc1 mRNA and a moderate increase of Mucl mucin, is obviated in CF mice that do not express the Mucl gene (Parmley and Gendler 1998), suggesting that the membrane-tethered mucin Mucl plays an important role in mucus obstruction in the $\mathrm{CF}$ colon.

Inspissated material is also found in the pancreas and bile ducts in CF patients and CF animal models. Although these tissues are not typically described as mucosal epithelia, the pancreas expresses MUC6 mRNA and the gallbladder expresses both MUC6 and MUC5B mRNA (Reid et al. 1997b; Hollingsworth 1999). Inspissated material in the pancreatic ducts of CF patients contains MUC6 mucin (Reid et al. 1997b; Hollingsworth 1999), whereas CF mice show higher Muc6 mRNA and protein levels than wild-type mice in their pancreatic ducts (Gouyer et al. 2010). These data suggest that the absence of functional CFTR/Cftr protein may impact regulation or secretion of MUC6/Muc6 mucin in 
S.M. Kreda et al.

the gastrointestinal tract and contribute to the formation of materials that block pancreatic acini and ducts in CF. Gallstones are frequent in CF patients and generally contain "black" pigment (i.e., Ca bilirubinate) with an appreciable cholesterol admixture. CF mice exhibit similar pathophysiological changes in their gallbladder bile (Freudenberg et al. 2010). Whether or not mucins are part of the gallstone admixture in $\mathrm{CF}$ bile is not yet known, but the biliary tract can express and secrete mucins in disease conditions (Gouyer et al. 2010).

In contrast to the gastrointestinal tract, there are no marked morphological abnormalities in the airways of $\mathrm{CF}$ fetuses or neonates, and mucus obstruction in CF airways is not observed prenatally or at birth (Zuelzer and Newton 1949; Sturgess and Imrie 1982). Postnatally, dilated acinar and duct lumens in submucosal glands are observed in CF airways early in life with the earliest consistent pathological lesion and evidence of mucus obstruction being observed in the bronchioles (Sturgess 1982). Nevertheless, pulmonary complications (reflecting predisposition to infection and recurring cycles of infection) result in airway mucus obstruction and progressive lung disease, which are the major cause of morbidity and mortality in CF patients (Boat et al. 1989; Welsh et al. 1995). The existence of mucus plugs containing mucins, bacteria, and neutrophils that block the lower airways of CF patients and of sputum with similar characteristics continue to support the concept of "abnormal" lung mucus and/or mucins in CF. Further exacerbating the problem of stagnant mucus in CF airways, the airway surface liquid of CF patients has decreased bactericidal activity (Smith et al. 1996), which may be due to the decreased lactoferrin activity observed in $\mathrm{CF}$ sputum (Rogan et al. 2004). In addition, CFTR transport of glutathione and its thiocyanate conjugates is defective in $\mathrm{CF}$ airways, inactivating the oxidative antimicrobial system in CF mucus (Childers et al. 2007; Moskwa et al. 2007).

Interestingly, genetic knockout of Cftr in mice does not cause lung disease, although the gastrointestinal phenotype of CF disease, meconium ileus, is duplicated in the CFTR-null mouse quite well (Snouwaert et al. 1992). The lack of CF lung disease in the mouse model reflects the dominant expression of a $\mathrm{Ca}^{2+}$-activated $\mathrm{Cl}^{-}$channel and poor expression of CFTR in the lungs. The mouse model that produces the best CF-like lung phenotype is the transgenic overexpression, selectively in Clara cells, of $\beta E N a C$, the $\beta$-subunit of the epithelial $\mathrm{Na}^{+}$ channel (Mall et al. 2004a; Zhou et al. 2011). The increased liquid absorption in the lungs of the $\beta \mathrm{ENaC} \mathrm{Tg}$ mouse appears to drive an inflammatory process that results in mucus metaplasia and overproduction, and mucus plugging (Livraghi et al. 2009). We pursue this "non-infectious inflammation" phenomenon below, after consideration of infectious inflammation.

\section{Mucin Glycoproteins}

Mucins are large glycoproteins with a carbohydrate content that accounts for $50 \%-90 \%$ of their molecular mass. They are characterized by a high number of $O$-glycans and an extensive number of tandem repeats (TRs) in their protein backbones that are high in threonine and/ or serine and proline, as well as domains specific to individual mucins (Fig. 1A,B). TR domains are a characteristic feature that distinguishes mucins from mucin-like glycoproteins, especially membrane-bound glycoproteins/receptors that have extracellular regions high in serine, threonine, and proline. Mucins are classified by their MUC protein backbones, which are encoded by one of 18 MUC genes, as membrane-tethered (MUC1, MUC3A, MUC3B, MUC4, MUC11, MUC12, MUC13, MUC16, MUC17, MUC20), secreted, polymeric, and cysteine rich (MUC2, MUC5AC, MUC5B, MUC6, MUC19) or secreted and non-cysteine rich (MUC7, MUC8, MUC9) mucins (Rose and Voynow 2006). Models of secreted mucins and the membrane-tethered MUC1 mucin are shown in Figure $1 \mathrm{~A}$ and B. MUC1 is typically expressed in the apical membrane of epithelial cells. Mucins show somewhat restricted tissue and cell specificity, which is often altered in disease states, especially cancer. The gel-forming mucins are synthesized in goblet and mucosal cells in epithelial tracts (Table 1) and stored in secretory granules until stimulated for luminal 
CFTR, Mucins, and Mucus Obstruction

Table 1. Human tissues (normal) expressing polymeric mucin glycoproteins

\begin{tabular}{|c|c|c|c|c|c|c|}
\hline Tissue & MUC2 & MUC5AC & MUC5B & MUC6 & MUC19 & References \\
\hline Salivary glands (sublingual) & & & $\mathrm{X}$ & & a & Zalewska et al. 2000 \\
\hline Nasal glands & & & $\mathrm{X}$ & & & Martinez-Anton et al. 2006 \\
\hline $\begin{array}{l}\text { Nasal septum and } \\
\text { nasopharynx }\end{array}$ & & $\mathrm{X}$ & & & & Martinez-Anton et al. 2006 \\
\hline $\begin{array}{l}\text { Airway superficial } \\
\text { epithelium (trachea and } \\
\text { bronchii) }^{\mathrm{b}}\end{array}$ & & $\mathrm{X}$ & & & & $\begin{array}{l}\text { Rose and Voynow 2006; } \\
\text { Thornton et al. } 2007\end{array}$ \\
\hline Airway submucosal glands & & & $\mathrm{X}$ & & & $\begin{array}{l}\text { Rose and Voynow 2006; } \\
\text { Thornton et al. } 2007\end{array}$ \\
\hline Stomach & & $\mathrm{X}$ & & $\mathrm{X}$ & & $\begin{array}{l}\text { Corfield et al. 2000; Linden } \\
\text { et al. } 2008\end{array}$ \\
\hline Small and large intestine & $\mathrm{X}$ & & & & & $\begin{array}{l}\text { Corfield et al. 2000; Linden } \\
\text { et al. } 2008\end{array}$ \\
\hline $\begin{array}{l}\text { Gallbladder and } \\
\text { hepatobilliary ducts }\end{array}$ & & & $\mathrm{X}$ & $\mathrm{X}$ & & Sasaki et al. 2007 \\
\hline Pancreatic ducts & & & & $\mathrm{X}$ & & $\begin{array}{l}\text { Reid et al. 1997b; } \\
\text { Hollingsworth } 1999\end{array}$ \\
\hline Cervix & & $\mathrm{X}$ & $\mathrm{X}$ & $\begin{array}{c}\mathrm{X} \\
(\mathrm{low})\end{array}$ & & Andersch-Bjorkman et al. 2007 \\
\hline Conjunctiva & $\begin{array}{c}\mathrm{X} \\
(\mathrm{low})\end{array}$ & $\mathrm{X}$ & c & & & Spurr-Michaud et al. 2007 \\
\hline
\end{tabular}

${ }^{\mathrm{a}} \mathrm{MUC19}$ mucin glycoprotein is expressed in saliva from rats, horses, pigs, and cows, but was not detected in human saliva (Rousseau et al. 2008).

${ }^{\mathrm{b}}$ Muc5b is expressed in Clara cells of wild-type (WT) mouse airways under control conditions, and during development and in mucus metaplasia (Zhu et al. 2008; Roy et al. 2011). Muc5ac is expressed during mucus metaplasia (Zuhdi Alimam et al. 2000; Zhu et al. 2008); however, the human MUC gene products expressed in healthy and inflamed human small airways (bronchioles) remain to be identified.

${ }^{\mathrm{c}}$ MUC5B appears to be expressed in lacrimal glands but was not detected in tears (Spurr-Michaud et al. 2007).

release by secretagogues (Kim et al. 2003; Davis and Dickey 2008).

\section{Mucus and Mucins in Healthy and CF Lungs}

Mucus and mucins provide a physiological barrier to environmental toxins and pathogens (Hollingsworth and Swanson 2004; Linden et al. 2008; Cone 2009) and are part of the first line of innate immune responses in the conducting airway epithelium (Knowles and Boucher 2002). Polymeric mucins are the major macromolecular components of lung mucus and form viscoelastic gels by interacting with other mucins and/or proteins (Fig. 1C) (Litt et al. 1974; Rose et al. 1979, 1987). MUC5AC and MUC5B are the predominant mucins in lung secretions. In healthy lungs, MUC5AC mRNA expression is restricted to goblet cells in the conducting airway epithelium. MUC5B mRNA is expressed in mucosal cells of the submucosal glands, but is also expressed in goblet cells in the second trimester during gestation (Reid et al. 1997a) and recently has been observed at the protein level in adult lungs (Fig. 2, left panel). Although altered localization of cellular expression of secretory mucin genes has been reported-MUC5B mRNA in goblet cells in patients with various obstructive lung diseases (Chen et al. 2001a) and MUC5AC protein in glandular cells of COPD patients (Caramori et al. 2009) - this has not been observed in CF lungs. However, in neonatal wild-type and $\mathrm{CF}$ piglets, both Muc5ac and Muc5b mucins are expressed in goblet cells in the conducting airway epithelium, whereas Muc5b, but not Muc5ac, is expressed in glandular cells. Interestingly, the submucosal glands of CF piglets have 
S.M. Kreda et al.
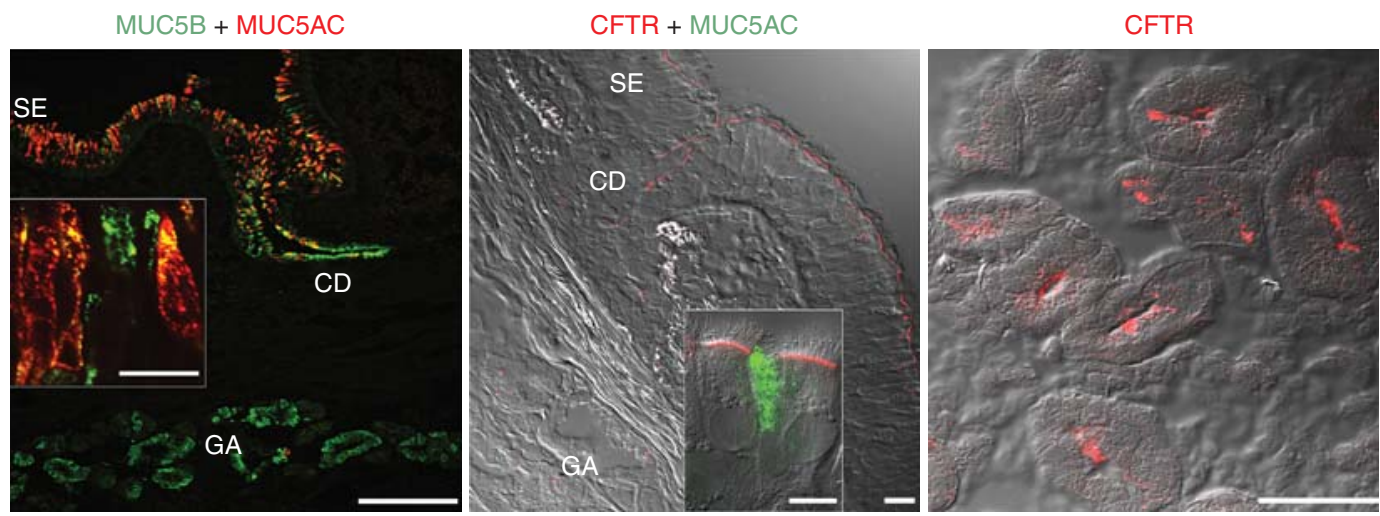

Figure 2. Immunolocalization of CFTR, MUC5AC, and MUC5B in normal human airway epithelium. (Left panel) Confocal microscopy overlay image of a human frozen bronchial section from a normal lung donor immunostained with antibodies against MUC5AC (clone 45M1) and MUC5B (VNTR region). MUC5AC expression is restricted to goblet cells of the surface epithelium, whereas MUC5B is expressed in the goblet cells of the surface epithelium and predominantly in submucosal glands both in the ciliated ducts (CD) and acini (GA) in a gradient pattern with the highest levels in the acini. Scale bar, $200 \mu \mathrm{m}$. (Inset) Goblet cells of the surface epithelium show that MUC5B is present in the surface epithelium and can be coexpressed with MUC5AC. Scale bar, $20 \mu \mathrm{m}$. (Center panel) Confocal microscopy image of a frozen section of human bronchus immunostained with a CFTR antibody. Images represent an overlay of the differential interference contrast (DIC) (gray) and CFTR immunofluorescence (red) confocal channels, and indicate that CFTR protein is mainly localized in the apical membrane of ciliated cells of the surface epithelium and ciliated ducts; CFTR immunostaining is negligible in serous cells of the gland acini. Scale bar, $20 \mu \mathrm{m}$. (Only $\sim 20 \%$ of normal bronchial specimens display CFTR immunostaining in glandular serous cells.) (Inset) Confocal image of coimmunostaining of CFTR and MUC5AC in primary cultures of human bronchial epithelium indicating that CFTR is not immunolocalized in goblet cells. Scale bar, $10 \mu \mathrm{m}$. (Images from Kreda et al. 2005; reproduced, with permission, from ASCB/ Molecular Biology of the Cell.) (Right panel) Confocal microscopy images of CFTR immunolocalization in the gland acini of human nasal epithelium. CFTR is localized in the apical membrane of serous cells in $\sim 50 \%$ of normal nasal specimens (Kreda et al. 2005). Scale bar, $20 \mu \mathrm{m}$. SE, surface epithelium; CD, ciliated duct; GA, gland acini.

reduced Muc5b immunostaining relative to gland volume, suggesting that mucous cell development is reduced and that airway changes that begin during fetal life may contribute to $\mathrm{CF}$ pathogenesis and clinical disease during postnatal life (Meyerholz et al. 2010).

MUC5AC and MUC5B mucins are overproduced in CF lung secretions (Kirkham et al. 2002), especially following exacerbations (Henke et al. 2007). An earlier report that MUC5AC and MUC5B mucin levels are decreased in CF sputum (Henke et al. 2004) highlights the challenges inherent in analyzing CF lung sputum. Early studies in the field identified differences in levels of mucins and the presence of DNA and inflammatory markers in CF sputum (Boat et al. 1976). Biochemical studies show that CF lung mucins in sputum are heterogeneous in size, likely reflect- ing digestion of mucins by proteinases in $\mathrm{CF}$ sputum (Rose et al. 1987). MUC5AC mucin is degraded by neutrophil elastase (Voynow et al. 1999; Henke et al. 2011), as is MUC5B mucin (Henke et al. 2011). MUC2 mucin or peptides are barely detectable in normal (Hovenberg et al. 1996a,b) or CF sputum (Davies et al. 1999; Kirkham et al. 2002), although MUC2 mRNA is well expressed in CF bronchial explants and is up-regulated by Pseudomonas aeruginosa lipopolysaccharide (Li et al. 1997) and other inflammatory mediators. Taken together, these data indicate that inflammatory mediators and bacterial byproducts in CF lungs contribute to the overproduction of mucins in vivo, as they do in vitro (for review, see Rose and Voynow 2006).

Knowledge of CFTR genotypes has taught us important lessons about CF (Dorfman et al. 
2010), but not enough to completely predict phenotype and disease severity, which has resulted in searches for genetic modifiers in CF patients. A few mucin genes have now been evaluated with regard to their variable number of TR lengths (Guo et al. 2011). A significant association of a $6.4-\mathrm{kb}$ TR in the MUC5AC gene is associated with severity of CF lung disease, suggesting that this polymeric mucin gene may be a genetic modifier for $\mathrm{CF}$ lung disease. No strong associations were found for MUC1, MUC2, or MUC7 mucin genes. Whether the genes that encode the polymeric MUC5B or the membrane-tethered MUC4 and MUC16 mucins are also genetic modifiers of CF lung disease remains to be established.

\section{IMPACT OF CFTR EXPRESSION ON MUCUS PRODUCTION IN CF}

\section{Overview}

One of the most important aspects of understanding the pathogenesis and pathophysiology of CF with regard to the mucus problem in CF involves understanding CFTR expression at the cellular and tissue levels. The organs that show pathophysiology in CF patients are those of epithelial origin, especially mucosal epithelia (Quinton 1990; Mall et al. 2004b; Kreda et al. 2005). As detailed below, CFTR expression and function have been described in epithelial cells of upper and lower respiratory tracts (Trezise and Buchwald 1991; Engelhardt et al. 1992, 1994; Trezise et al. 1993; Kalin et al. 1999; Penque et al. 2000; Carvalho-Oliveira et al. 2004; Kreda et al. 2005); the gastrointestinal tract (Trezise and Buchwald 1991; Tizzano et al. 1993; Manson et al. 1997; Kalin et al. 1999; Mall et al. 2004b), including pancreatic glands (Crawford et al. 1991; Marino et al. 1991; Trezise and Buchwald 1991; Tizzano et al. 1993; Trezise et al. 1993), liver and gallbladder (Tizzano et al. 1993; Yang et al. 1993); salivary glands (Trezise and Buchwald 1991; Best and Quinton 2005); and male and female reproductive tracts (Trezise and Buchwald 1991; Tizzano et al. 1993, 1994b; Trezise et al. 1993). However, CFTR is also expressed and functional in epithelia that lack mucus secreting cells-for example, sweat ducts (Quinton 1983, 1990; Cohn et al. 1991; Kartner et al. 1992; Claass et al. 2000; Kreda and Gentzsch 2011) and kidney (Jouret and Devuyst 2009)-but show ion transport abnormalities in CF. Furthermore, CFTR expression has been detected in non-epithelial tissues such as heart (Davies et al. 2004), brain (Mulberg et al. 1998; Robert et al. 2004), smooth muscle (Robert et al. 2004), and lymphocytes (Yoshimura et al. 1991), and the contribution of these sites to epithelial organ damage and CF disease, although underinvestigated, may be significant (Tirouvanziam et al. 2002; Bruscia et al. 2009; Hodges and Drumm 2009).

Although epithelial and non-epithelial tissues show CFTR-associated chloride and $\mathrm{HCO}_{3}^{-}$ transport abnormalities in $\mathrm{CF}$ patients, the most severe lesions responsible for CF morbidity are the result of mucus-based obstructions (often chronically infected) in the lumens of organs that support epithelial gel-forming mucin production (i.e., airways, intestine, and reproductive organs) (Boat et al. 1989; Tizzano and Buchwald 1995; Welsh et al. 1995). That some mucus-producing organs do not show obstructive or severe complications in CF (e.g., salivary and lacrimal glands) (Tizzano and Buchwald 1995; Castagna et al. 2001) has obscured the linkage of CFTR expression/deficiency with mucus production/obstruction, and ultimately, with organ failure. As a consequence, several hypotheses have arisen to explain the relationship between CFTR deficiency and mucus obstruction across different organs. The hypotheses fall into two broad categoriesone represented by the concept that mucus obstruction and organ failure is a direct consequence of epithelial CFTR deficiency, the other that mucus obstruction and organ failure occur secondarily to epithelial CFTR deficiency. The hypothesis that CFTR is involved directly in mucus production (i.e., mucin synthesis, posttranslation modifications, trafficking, secretion, and/or postsecretion modifications) holds that CFTR deficiency results in mucins with abnormal physicochemical qualities, favoring luminal accumulation, abnormal adhesion, and infection (Barasch et al. 1991; Barasch and al-Awqati 
S.M. Kreda et al.

1993; Zhang et al. 1995; Xia et al. 2005; Quinton 2010). However, this hypothesis has never been unequivocally confirmed, as detailed below.

The second possibility, that CFTR is indirectly related to mucus obstruction, has given rise to several hypotheses. One is the "dehydration hypothesis," in which mutated CFTR fails to contribute to the ionic drive needed for appropriate hydration of the mucus layer, resulting in thick mucus with concentrated mucins that collapses onto the underlying epithelium as a first step toward chronic infection and organ disease (Matsui et al. 1998; Boucher 2007; Chen et al. 2010). Another is the "innate immune hypothesis" wherein mutated CFTR results in abnormal mucus with diminished expression/ activity of epithelial antimicrobial molecules important for homeostasis following inflammation and infection, thereby contributing to chronic infection and organ disease (Smith et al. 1996; Zabner et al. 1998). When focused on altered secretion of innate immune proteins by the submucosal glands, this hypothesis is termed "the serous cell malfunction hypothesis" because airway serous cells require CFTR for the secretion of the antimicrobial-rich fluid elaborated by submucosal glands in response to irritants. In CF, fluid secretion by these cells is greatly diminished, resulting in airway mucus that is thicker (Wine and Joo 2004; Ballard and Spadafora 2007).

\section{CFTR Expression}

One of the most controversial aspects of CFTR studies has been the elucidation of CFTR expression in non-CF and CF organs. The rationale for these studies has been that determining the localization and levels of CFTR in different organs will help to elucidate the pathogenesis of $\mathrm{CF}$ and thus better direct the design of effective therapies. For the last 20 years, many laboratories using different experimental approaches (i.e., expression and localization of CFTR mRNA and protein and functional assessment of ion channel activity) have pursued studies producing some common findings, as well as some more controversial results. In analyzing the published data, it is necessary to take into account the experimental design and the reagents used, in particular the CFTR antibodies used to produce CFTR expression data in native tissues by means of immunostaining and western blotting. For example, a few studies, which produced controversial expression data in native tissues, used CFTR antibodies that were subsequently reported to perform differently according to tissue quality and histological techniques (Claass et al. 2000; Kreda and Gentzsch 2011). Not all antibodies are created equal, and rigorous controls and independent techniques should be used in parallel to detect low levels of CFTR protein expression in native tissues. Currently, highly sensitive and specific CFTR antibodies are readily available through the North America CF Foundation, and detection techniques are much improved, which has allowed scientists in the field to confirm or challenge expression data reported earlier. In the next sections, some of the key findings on CFTR mRNA and protein expression in the most severely affected organs are discussed from the perspective of the "mucus problem."

\section{CFTR Expression in Goblet Cells of the Respiratory and Gastrointestinal Tracts}

Notably, the most severe and life-threatening complications of CF disease are associated with aberrant mucus that obstructs and infects the airway and intestinal lumens, but the functional relationships between CFTR and goblet cells in those organs have not been completely defined. With the exception of a few immunostaining studies reporting CFTR expression in goblet cells of airway and intestinal tissues (Jacquot et al. 1993; Dray-Charier et al. 1995; Kalin et al. 1999), most studies fail to detect significant levels of expression (or channel activity) in goblet cells. As we review below, CFTR expression/activity, instead, is mainly localized apically not to MUC5AC-expressing goblet cells, but to the neighboring epithelial cells (Fig. 2, center panel) known to be involved in ion and fluid transport. Thus, aberrant mucus production appears to be secondary to defective, CFTRdriven ion composition and/or fluid volume in CF epithelia (Kreda et al. 2010; Quinton 
2010; Wine et al. 2011). Yet, evidence of chemical differences (e.g., terminal glycosylation with regard to sulfation, sialylation, fucosylation, and carbohydrate composition) in CF mucins (Cheng et al. 1989; Barasch et al. 1991; Barasch and al-Awqati 1993; Zhang et al. 1995; Xia et al. 2005) might implicate a direct role for CFTR in the posttranslational processing of mucins (see section below: Mucin Glycosylation and $\mathrm{CF})$. Because the glycosylstransferases requisite for $O$-glycosylation are predominant in goblet and mucous cells, it would imply that CFTR activity is present in intracellular compartments and is necessary for proper mucin biosynthesis. Emerging technical advances in the field of mucin chemistry and goblet cell and mucin granule isolation will allow us to address these important questions in the near future; however, as the following subsections indicate, the available evidence suggests that CFTR is absent from mucin-secreting cells (Fig. 2, center and right panels), with the exception of pancreatic and hepatobiliary ductal epithelia whose simple, cuboidal epithelial cells express CFTR and are responsible for both transepithelial ion and fluid transport and mucin secretion (Hollingsworth 1999; Kuver et al. 2000; Sasaki et al. 2007).

\section{CFTR Expression in the Upper and Lower Respiratory Tracts}

CFTR transcripts are expressed during development in the pseudoglandular epithelium of the human fetal primordial lung (Tizzano et al. 1994a). Subsequently during fetal development, CFTR expression decreases in the alveoli and is gradually restricted to the surface epithelium in the large and small airways, and not detected in fetal submucosal glands (Tizzano et al. 1993, 1994a; Trezise et al. 1993). In contrast, in the neonatal period, CFTR mRNA expression decreases in the surface of the conductive airway epithelia but appears gradually in the submucosal glands (Tizzano et al. 1993, 1994a; Trezise et al. 1993). In the adult lung, although the level of CFTR mRNA expression is lower than in the fetal lung, mRNA is observed in the surface epithelium of nose, trachea, bronchi, and proximal bronchioles, while being scarce in the distal bronchioles and alveoli (Engelhardt et al. 1994; Kreda et al. 2005). In the airway submucosal glands, CFTR mRNA expression appears to decrease distally toward the acini (Engelhardt et al. 1994; Kreda et al. 2005). Interestingly, this pattern of CFTR mRNA expression appears to be at odds with CF pathogenesis. For example, CFTR expression is highest during fetal life, but $\mathrm{CF}$ lungs are mostly normal at birth; similarly, $\mathrm{CF}$ lung disease develops in the infant and is the primary cause of mortality of young and adult CF patients (Boat et al. 1989), despite low levels of CFTR expression at these ages. Moreover, submucosal gland hyperplasia is one of the earliest pathogenic changes, yet CFTR expression in the glands is seen only after birth (Tizzano et al. 1994a).

\section{Immunolocalization of CFTR Protein Does Not Correlate with CFTR mRNA in Lung Tissues}

Localization of CFTR protein is hindered by the capability of CFTR antibodies to detect low levels of protein expressed in adult human lung tissues. Consequently, CFTR expression data, by means of immunostaining, can vary according to the CFTR antibodies used and do not always reflect mRNA expression (Kreda and Gentzsch 2011). For example, an early study by Engelhardt and collaborators, using a polyclonal antibody that recognizes the carboxyl terminus of CFTR, describes CFTR protein expression being associated mainly with the apical membrane of the serous cells in the submucosal glands, although mRNA expression was high in the superficial and gland ductal epithelia (Engelhardt et al. 1992, 1994). In contrast, a subsequent study by Kreda and collaborators, using very sensitive monoclonal antibodies recognizing the NBD2 domain of CFTR (Mall et al. 2004b), describes CFTR protein expression mainly in the apical membrane of all ciliated cells in the epithelium lining the nose and all airway regions, including submucosal gland ducts; however, CFTR protein was not obviously expressed in the acinar cells of bronchial submucosal glands (Kreda et al. 2005). Interestingly, CFTR was detected in the glandular serous 
S.M. Kreda et al.

cells in $\sim 20 \%$ of normal bronchial specimens (Fig. 2, center panel) and in $50 \%$ of normal nasal specimens (Fig. 2, right panel) (Kreda et al. 2005). Despite both studies (Engelhardt et al. 1992; Kreda et al. 2005) showing a similar pattern of localization of CFTR transcripts in the human lung, the CFTR protein immunolocalization data are very different. The distribution of immunostaining signal described by Kreda et al. (2005) corresponds with the pattern of mRNA localization in the lung, suggesting that CFTR expression is important in the surface epithelia and that it decreases distally toward the acinar structures in the submucosal glands. However, in the airway glands, CFTR activity appears to be more important in the acinus than in the proximal ducts (Joo et al. 2002; Ballard and Inglis 2004; Ballard and Spadafora 2007; Wu et al. 2007b; Choi et al. 2009; Wine et al. 2011). Thus, one conclusion of these studies is that expression of CFTR gene products may not always predict accurately how critical CFTR activity might affect the physiological functions of a particular tissue or organ. Additionally, these data stress the need to validate immunostaining findings with alternative approaches to identify CFTR expression (i.e., western blotting and channel activity).

At the cellular level, most localization studies identify CFTR protein expression in the apical plasma membrane of ciliated cells in nasal and airway epithelia (Puchelle et al. 1992; Brezillon et al. 1995; Kalin et al. 1999; Penque et al. 2000; Carvalho-Oliveira et al. 2004; Kreda et al. 2005; Kreda and Gentzsch 2011) and the acinar serous cells of submucosal glands (Fig. 2) (Engelhardt et al. 1992; Kalin et al. 1999; Kreda et al. 2005), and more recently, in isolated type II alveolar cells (Brochiero et al. 2004; Bove et al. 2010). Although a few studies indicated CFTR localization in airway goblet cells (Jacquot et al. 1993; Kalin et al. 1999), most laboratories did not detect CFTR expression in mucous/goblet cells in human lung tissues (Engelhardt et al. 1992, 1994; Puchelle et al. 1992; Brezillon et al. 1995; Kalin et al. 1999; Kreda et al. 2005; Kreda and Gentzsch 2011), in primary cultures of airway epithelial cells (Kreda et al. 2005; Cholon et al. 2010), or in mucin-secreting cell lines derived from airway epithelia, for example, SPOC1 cells (Abdullah et al. 1997) and Calu-3 cells (Kreda et al. 2007). Calu-3 is an adenocarcinoma cell line that differentiates into two distinctive cell types: one that expresses high levels of functional CFTR in the apical membrane, and another that expresses MUC5AC mucins (Kreda et al. 2007). CFTR was not detected in mucin granule membranes isolated from Calu3 cells (Kreda et al. 2010; SM Kreda and J Sesma, unpubl.), even though Calu-3 cultures do express high levels of CFTR (Shen et al. 1994; Kreda et al. 2007). Thus, CFTR expression and channel activity in mucosal epithelia appear to be associated with cell types involved in ion/ fluid transport rather than with mucin-producing cells in the human lung.

\section{CFTR Expression in Human Gastrointestinal Organs}

Unlike the lung, the pattern of CFTR mRNA expression in the gastrointestinal track is similar in the fetus and adult, suggesting that CFTR performs similar functions in the fetal and adult gastrointestinal tracts (Crawford et al. 1991; Trezise et al. 1993; Strong et al. 1994) and is consistent with the fact that severe gastrointestinal disease is the initial pathological feature in CF (Park and Grand 1981; Boat et al. 1989). Already during fetal development, and continuing through life, high levels of CFTR mRNA expression are observed in the epithelium of all gastrointestinal regions (Tizzano et al. 1993; Strong et al. 1994). CFTR mRNA expression is highest in the duodenum and decreases along the small intestine. It is lowest in the colon and presents as a decreasing gradient of expression along the crypt-villous axis, with CFTR mRNA being lowest in the luminal half of the villus in all intestinal regions (Tizzano et al. 1993; Trezise et al. 1993; Strong et al. 1994). High levels of CFTR mRNA are also observed in the Brunner's glands (Strong et al. 1994) and in the ductal and centroacinar cells at later development stages and in the adult (Tizzano et al. 1993; Trezise et al. 1993; Strong et al. 1994). In the liver, CFTR mRNA is localized to the epithelia of bile ducts and ductules, whereas in the gallbladder, high 
levels of CFTR mRNA are observed in the epithelium, with no expression detected in the hepatocytes or bile canaliculi (Tizzano et al. 1993; Trezise et al. 1993; Strong et al. 1994).

Importantly, the pattern of CFTR mRNA expression is indicative of the pathological changes observed in the gastrointestinal track of affected CF individuals (Crawford et al. 1991; Tizzano et al. 1993; Trezise et al. 1993; Strong et al. 1994). Meconium ileus and intestinal mucus-based obstruction are among the earliest manifestations of CF (Duchatel et al. 1993) and may reflect a failure in utero to proteolytically digest swallowed and sloughed proteins, which may include mucins. Distal intestinal mucus-based obstruction occurs in $>20 \%$ of adult patients. Ductal obstruction and dilation in the Brunner's glands, the crypts of Lieberkuhn, and the pancreas have been observed in affected fetuses, while pancreatic insufficiency requires oral enzyme supplementation in $\sim 85 \%$ of CF patients. Similarly, liver disease characterized by excessive accumulation of mucus in bile ducts and ductules is observed already early in life and evolves in focal biliary fibrosis and cirrhosis, affecting 20\%-50\% of all CF patients (Park and Grand 1981; Boat et al. 1989; Tizzano et al. 1993; Yang et al. 1993).

\section{Immunolocalization of CFTR Protein Correlates with CFTR mRNA Findings in Gastrointestinal Tissues}

As in the lung, the quality of the antibodies and techniques used must be taken into account in analysis of CFTR immunolocalization data in gastrointestinal tissues (Fig. 2). In the human stomach, CFTR immunolocalizes to the epithelium but at low levels (SM Kreda, unpubl.). In the intestine, CFTR immunolocalizes specifically to the apical membrane of enterocytes in the crypts and villi of the small intestine (Mall et al. 2004b; Kreda and Gentzsch 2011) and the crypts of the jejunum and colon (Crawford et al. 1991; Mall et al. 2004b); CFTR protein immunostaining is more prominent in the base decreasing toward the tip of the crypts (Mall et al. 2004b; Kreda and Gentzsch 2011), following the pattern of CFTR mRNA expression. In the pancreas, liver, and gallbladder, CFTR immunostaining also reflects the pattern of mRNA expression, with CFTR protein being detected chiefly in the apical membrane of non-mucous cells (Crawford et al. 1991; Marino et al. 1991; Cohn et al. 1993; Yang et al. 1993). Although goblet cell hyperplasia is present in all gastrointestinal regions and mucus obstruction is a feature of gastrointestinal CF disease (Park and Grand 1981; Boat et al. 1989; Tizzano et al. 1993), most studies have failed to detect CFTR immunostaining associated with goblet cells in the GI epithelia, even using epitope retrieval and other signal-enhancing techniques (Mall et al 2004b; Kreda and Gentzsch 2011). A few studies reported CFTR immunostaining associated specifically with intracellular organelles of goblet cells, in all intestinal regions (Kalin et al. 1999) and in the gallbladder (Kuver et al. 2000); however, the antibodies used in these studies have been reported to produce unexpected results in human tissues (Claass et al. 2000). Moreover, CFTR is immunolocalized to the apical membrane of enterocytes in murine intestine, and no CFTR expression was observed in goblet cells in the proximal and distal intestine (Jakab et al. 2011). The selective expression of CFTR in the enterocytes supports a role of CFTR in regulating ion and fluid transport in the human and rodent intestine (Garcia et al. 2009).

\section{CFTR Expression in the Reproductive Organs}

Virtually all CF males are azoospermic because of atrophy and obstruction of the epididymis, vas deferens, and seminal vesicles. These pathological changes have often been interpreted as a secondary lesion to mucus-based obstruction of the epididymis and vas deferens ductal system (Tizzano et al. 1994b). Accordingly, CFTR mRNA is expressed mainly in the ductal epithelial cells of the epididymis in the human male fetus, newborn, and infant (Trezise and Buchwald 1991; Tizzano et al. 1993, 1994b). In adults, the epithelium of the epididymis and vas deferens shows a high level of CFTR mRNA expression, whereas low mRNA expression is observed in testis, prostate, or seminal vesicles throughout life (Tizzano et al. 1994b). 
S.M. Kreda et al.

CFTR immunostaining reflects mRNA expression and is observed at the luminal surface of epithelial cells of the efferent ducts and the epididymis (Hihnala et al. 2006; Kujala et al. 2007). In the seminal vesicles and prostate, no immunostaining is observed in the glandular epithelium, but strong labeling for CFTR is present on the luminal surface of the ductal epithelium (Hihnala et al. 2006; Kujala et al. 2007). CFTR is also immunolocalized to the equatorial segment of human and mouse spermatozoids (Hihnala et al. 2006; Kujala et al. 2007; Xu et al. 2007). More studies are needed to understand the link between CFTR deficiency and the pathological changes in the CF male reproductive tract.

Females with CF have reduced fertility, but the underlying causes are not well understood. Infertility has been proposed to be mainly a consequence of abnormally thick, dense cervical mucus that presents a barrier for sperm penetration and transport to the egg (Brugman and Taussig 1984; Tizzano et al. 1994b; Hodges et al. 2008). However, altered ion and fluid transport (due to CFTR deficiency) throughout the female reproductive track, endocrine abnormalities, and menstrual irregularities may also account for infertility in women and mouse models with CF (Brugman and Taussig 1984; Tizzano et al. 1994b; Hodges et al. 2008; Chan et al. 2009). Expression of CFTR mRNA is evident in the female fetus after the third trimester in the epithelium of the uterine cervix and the Fallopian tube (Tizzano et al. 1993). In newborns and infants, CFTR mRNA expression is found at high, moderate, and low levels in the epithelium and glands of the cervix, the Fallopian tubes, and the endometrium, respectively; whereas in adults, a high level of mRNA expression is detected in the cervix and to a lesser degree in both endometrium and Fallopian tubes; no expression was observed in ovaries at any age (Tizzano et al. 1994b). By immunostaining, CFTR has been observed in the apical surface of uterine and oviduct epithelial cells involved in fluid secretion (Rochwerger and Buchwald 1993). In the Fallopian tubes, CFTR is localized specifically to the apical membrane of epithelial cells (Ajonuma et al. 2005). CFTR immuno- staining is also present in the apical membrane of fluid-secreting cells of the endocervix (SM Kreda, unpubl.). The levels of CFTR mRNA expression change during the menstrual and (estrous) cycle in the female reproductive track (Hodges et al. 2008; Chan et al. 2009). Whether these changes correlate with the fluctuations in levels of specific mucins and alterations in mucin glycosylation and physical properties that occur during estrous has not yet been evaluated as far as we are aware, but may be informative in understanding the impact of CFTR on mucins and mucosal components in an epithelial tract that is not typically infected in CF.

\section{CFTR Expression in the Organs of CF Patients}

The pattern of expression of mRNA transcripts for $\Delta$ F508 CFTR (the most frequent mutation in the Caucasian population) and wild-type CFTR is similar in human tissues, indicating that there is no significant defect at the level of mRNA expression in ( $\Delta$ F508) CF tissues (Trapnell et al. 1991; Engelhardt et al. 1992). However, the protein expression and localization of mutated CFTR, in particular $\Delta$ F508 CFTR, have produced different results depending on the antibodies used. For example, most CFTR antibodies recognize wild-type CFTR protein at the apical membrane of epithelial cells in sweat ducts from normal but not from $\Delta$ F508 homozygous individuals (Quinton 1990; Cohn et al. 1991; Kartner et al. 1992; Kalin et al. 1999; Claass et al. 2000; Kreda and Gentzsch 2011), in agreement with the concept that the absence of protein in the apical membrane of epithelial cells in $\Delta$ F508 homozygous tissues reflects lack of fully glycosylated CFTR protein and channel activity in those tissues (Cheng et al. 1990; Quinton 1990; Cohn et al. 1991; Marino et al. 1991; Puchelle et al. 1992; Zeng et al. 1997; Mall et al. 2004b; Kreda et al. 2005; Kreda and Gentzsch 2011; Thomas and Lukacs 2012). In contrast, a few immunostaining studies reported that localization of human $\Delta$ F508 CFTR did not differ from wild-type CFTR in airway and intestinal tissues (Dray-Charier et al. 1995; Dupuit et al. 1995; Kalin et al. 1999; Penque et al. 
2000). However, with the availability of CFTR antibodies of high sensitivity and specificity and sensitive confocal microscopy techniques, these issues have been revisited. In these studies, $\Delta$ F508 CFTR protein was not detected in the apical membrane of epithelial cells in native tissues and primary cell cultures from human nose and lung and intestine (Mall et al. 2004b; Kreda et al. 2005; Kreda and Gentzsch 2011), as originally observed in the sweat duct of CF patients (see above). These observations reflect the loss of processing and trafficking of CFTR that occurs in mutated CFTR (see Riordan 2012).

\section{MUCIN OVERPRODUCTION IN CF}

\section{Overview}

Several processes can account for mucin overproduction and increased mucin levels in the human respiratory tract, including hypersecretion of mucins, proteolytic cleavage of membrane-tethered mucins, up-regulation of MUC gene expression, and epithelial remodeling by goblet cell hyperplasia/metaplasia and/or glandular hyperplasia (for review, see Rose and Voynow 2006). A network of genes that transcriptionally mediate goblet cell metaplasia/hyperplasia in murine and human epithelium is emerging (Chen et al. 2009). In CF lung epithelial, patches of goblet cell hyperplasia were observed (Voynow et al. 2005). In contrast, goblet cell hyperplasia is not observed in CF bronchial biopsies, although an increase in goblet cell size in CF tissue, as well as a fourfold increase in submucosal gland volume, was reported (Hays and Fahy 2006). It is worth noting, however, that goblet cell size is not necessarily a good marker of mucin production, because a cell in which mucin synthesis is elevated could be secreting mucins at an equal rate. In fact, at this point, we have no idea of the cellular mechanisms regulating the quantity of mucin stores in goblet cells.

In the murine conducting airway epithelium, allergenic sensitization and challenge or the Th2 cytokine IL13 induce mucus cell metaplasia, and thus expression of Muc5ac in goblet cells (Zuhdi Alimam et al. 2000). It is now clearly evident that murine lung secretory cells ex- press Muc5b at baseline conditions and transdifferentiate to goblet cells that express Muc5b and Muc5ac in response to allergenic sensitization and challenge (Zhu et al. 2008). Based on these studies and studies on mucin gene expression during development of mouse lungs (Roy et al. 2011) and mucin gene knockout studies (C Evans, unpubl.), emerging paradigms are that Muc5b is an intrinsic component of homeostatic mucosal defense in murine lungs and that both Muc5ac and Muc5b genes can be up-regulated in vivo by mediators activated during inflammation and infection. The relevance of these concepts to human lung diseases, especially CF, will unfold further as studies are performed in Cftr ferrets and pigs, which have abundant submucosal glands and thus more closely resemble human airways.

A suggestion that appears to arise periodically is that it is the exocytic secretion of mucins that is affected in CF. The existing data, however, do not support this notion. Basal- and agoniststimulated mucin secretion are not different in primary cultures of airway epithelial cells from non-CF and CF individuals (Fig. 3A) (Lethem et al. 1993) or from non-CF sources treated with CFTR inh172, a potent CFTR inhibitor (Fig. 3B) (Hodges and Drumm 2009). Another suggestion, discussed briefly below (see section on $\mathrm{Mu}$ cin Secretion and Regulation), in favor for several years, held that a dysfunctional CFTR was responsible for changes in glycosylation, sulfation, and sialylation of CF mucins. However, this would require expression of CFTR in goblet cells, which is not supported by current data, as addressed above. The current paradigm is that the various processes that drive mucin overproduction and hypersecretion are directed to a large extent by inflammation and are predominantly impacted by mechanisms that drive mucin gene regulation and mucin secretion. These are independent processes, although the terms "mucin production" and "mucin secretion" are still sometimes used interchangeably in the literature. Understanding how mucin gene regulation and secretion are modulated during inflammation in CF airways is a fundamental question that remains to be answered. Thus, recent information on mucin gene regulation and 
S.M. Kreda et al.

A

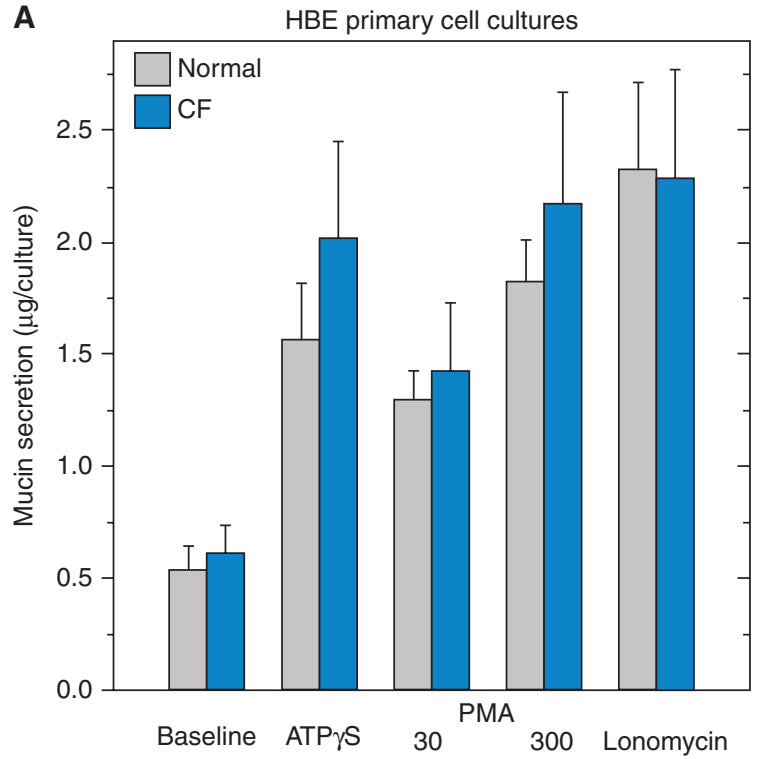

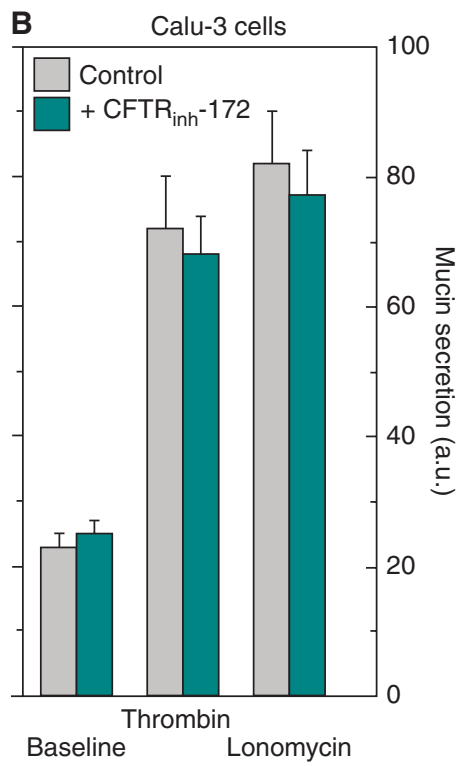

Figure 3. Mucin secretion in human bronchial epithelial cell cultures from healthy (normal) and CF individuals $(A)$, and from Calu-3 cells exposed to CFTR inh-172 (B). Mucin secretion, assessed as described in Abdullah et al. (2012) and Kreda et al. (2007), was not affected in either case. The data are expressed as the mean \pm S.E.: HBE cell culture data (LH Abdullah and CW Davis, unpubl.) $(n=6)$; Calu-3 cell data (S Kreda, unpubl.) $(n=3)$. a.u., arbitrary units.

mucin secretion potentially relevant to our understanding of CF lung disease is reviewed below.

\section{Mucin Gene Regulation}

Multiple stimuli (bacterial, viral, inflammatory) induce overproduction of polymeric mucins by up-regulating expression of polymeric mucin genes. This regulation is complex and can be both cell and mucin gene specific. Transcriptional up-regulation of MUC gene expression is activated following binding of mediators to membrane receptors on secretory cells, resulting in activation of various signal transduction pathways and transcription factors that then translocate to the nucleus and bind to cis-sites on MUC gene promoters. Typically, studies initially use lung epithelial cancer cell lines (NCIH292 and A549) and/or immortalized lung epithelial cell lines, for example, HBE1 cells (Yankaskas et al. 1993) or 16HBE cells (SV40 virus-transformed, immortalized HBE cell lines) (Bruscia et al. 2002). To assess the rele- vance of observations, findings are then evaluated in primary differentiated human bronchial epithelial (HBE) or human nasal epithelial (HNE) cells. ${ }^{6}$ These latter cells differentiate to a polarized epithelium with ciliated, goblet, and basal cells when grown under air-liquid interface conditions and are model systems that morphologically recapitulate the conducting epithelium of the respiratory tract ( Wu et al. 1990; Kondo et al. 1993; Gruenert et al. 1995). Some mechanisms present in lung cancer cell lines are lacking in HBE cells, and instances are pointed out below. This reinforces the importance of validating results obtained in cancer or immortalized cell lines with differentiated HBE cells or animal models that reflect human airways when investigating therapies for mucus overproduction. In the sections below, the experimental cell types used are stated, rather than the generic term "lung epithelial cells."

${ }^{6}$ Here these model systems are referred to as differentiated HBE or HNE cells. 
Most of the literature with regard to mediators that increase MUC2, MUC5AC, and MUC5B gene expression from 1995 to 2005 was recently reviewed (Rose and Voynow 2006), and schematics identifying the impact of these pathways on specific cis-sites in the promoters of
MUC2, MUC5AC, and MUC5B genes (Thai et al. 2008) or the MUC5AC gene (Voynow and Rubin 2009) have been published. This section attempts to update and integrate information recently reported and focuses on regulation of the MUC5AC (Fig. 4) and MUC5B

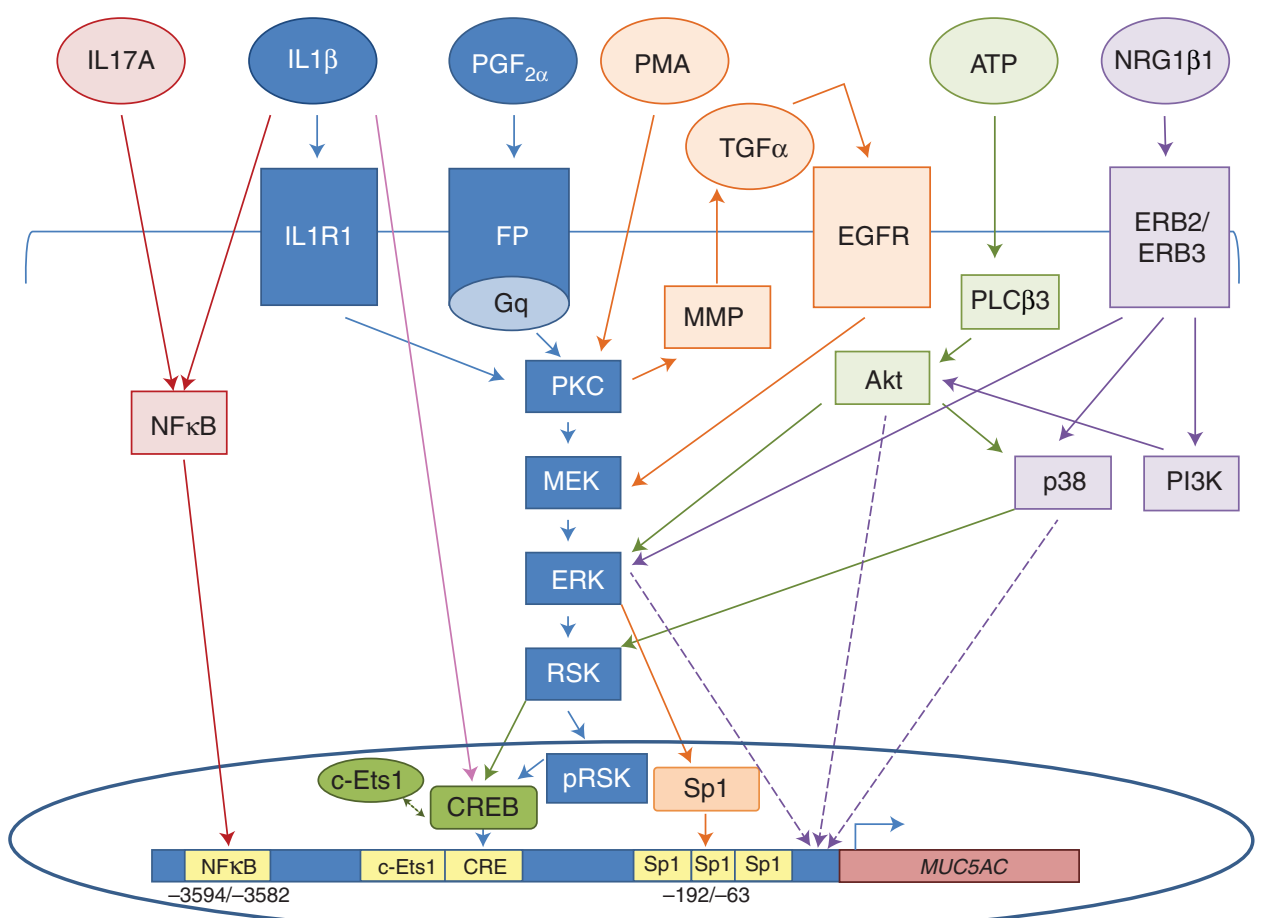

Figure 4. MUC5AC gene expression is transcriptionally regulated by various mediators and pathways. The figure depicts mediators, receptors, and cis-sites reported since earlier reviews on regulation of MUC5AC gene expression (Rose and Voynow 2006; Thai et al. 2008; Voynow and Rubin 2009). Each reference is color-coded by arrows. (Red) IL1 $\beta$ and IL17A induce MUC5AC expression by activation of the NFKB cis-site at $-3594 /-3582 \mathrm{bp}$. Direct binding of the NFKB p50 subunit was observed in HBE1 cells (Fujisawa et al. 2009). (Blue) PGF $_{2 \alpha}$ signals through the prostaglandin F receptor (FP), which is coupled to the Gq protein to activate PKC, which then signals through an MEK, ERK, RSK pathway. RSK translocates to the nucleus after phosphorylation and activates CREB to bind to the CRE cis-site $(-878 /-871)$ to up-regulate MUC5AC expression in differentiated HBE cells and NCI-H292 cells. A model summarizing the mechanisms whereby prostaglandins and IL1 $\beta$ induce MUC5AC overexpression has been reported (Chung et al. 2009). (Pink) CREB binds maximally to the CRE cissite in the MUC5AC promoter $2 \mathrm{~h}$ after IL1 $\beta$ exposure to A549 or differentiated HBE cells (YA Chen, AM Watson, LM Garvin, et al., unpubl.). (Orange) PMA activates the PKC isoforms $\delta$ and $\theta$, resulting in activation of matrix metalloproteinase (MMP) and secretion of TGF $\alpha$, which binds to its cognate receptor EGFR. EGFR activates the MEK/ERK1/2 pathway to activate Sp1, which binds to three Sp1 sites $(-192 /-63)$ in the MUC5AC promoter. Similar results were obtained in H292 cells (Hewson et al. 2004) and in differentiated HBE and HBE1 cells (Yuan-Chen et al. 2007). (Green) ATP exposure to H292 cells induces MUC5AC expression by activating PLC 33 , which, in turn, activates Akt to signal through ERK or p38 to activate RSK, thereby activating CREB and c-Ets1 binding to the CRE $(-889 /-869)$ and c-Ets1 $(-938 /-930)$ sites in the MUC5AC promoter (Song et al. 2008). (Purple) Neuregulin $1 \beta 1$ (NRG1 $\beta 1$ ) signals through the ERB2/ERB3 heterodimer receptor to activate three different pathways: $\mathrm{p} 38$, ERK1/2, and PI3K, which signals through Akt to up-regulate MUC5AC gene expression in differentiated HBE cells (Kettle et al. 2010). 
S.M. Kreda et al.

(Fig. 5) genes, which account for mucin overproduction in human lungs.

\section{Transcriptional Regulation of Secretory Mucin Genes}

Ligand binding to cognate membrane receptors - for example, the epidermal growth factor receptor (EGFR, i.e., ErbB1, a member of the ErbB family of receptor tyrosine kinases), IL1R1, FP (Prostaglandin F receptor) — activates specific signal transduction pathways many of which converge or interact (Figs. 4 and 5). This results in nuclear translocation and/or phosphorylation of specific transcription factors, for example, CREB (cyclic AMP response element-binding), NFкB (nuclear factor $\kappa$ light-chain-enhancer of activated B-cells), or Sp1 (specificity protein 1), which bind to specific cis-sites on polymeric MUC gene promoters. A predominant mechanism for regulating MUC2 and MUC5AC gene expression is via activation of EGFR, which results in activation of extracellular signal-related kinases (ERK) 1,2 (Takeyama et al. 1999; Lemjabbar and Basbaum 2002). Recent data show that the TGF $\alpha$-induced up-regulation of MUC5AC gene expression in NCI-H292 cells is mediated via the EGFR-

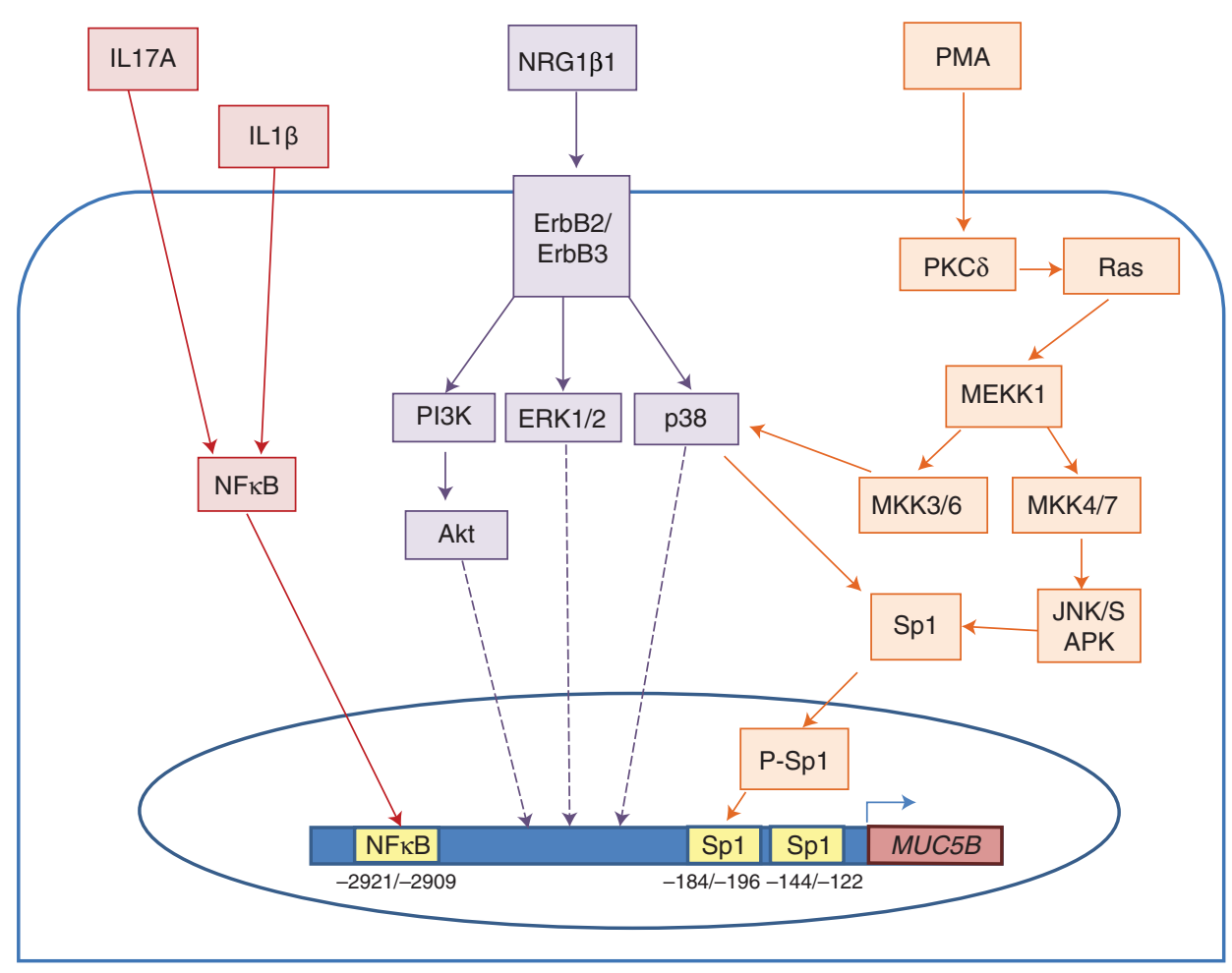

Figure 5. MUC5B gene expression is transcriptionally regulated by various mediators and pathways. (Red) IL1 $\beta$ and IL17A induce MUC5B gene expression by activation of the NFKB cis-site at $-2921 /-2909$ bp in the MUC5B promoter. Direct binding of the NFкB p50 subunit was observed by ChIP in HBE1 cells (Fujisawa et al. 2011). (Orange) PMA activates PKC $\delta$, which signals through Ras to activate MEKK1, which then signals through either a p38 pathway or the JNK pathway to phosphorylate Sp1, which binds to the Sp1 site at $-184 /-196$. The Sp1 cis-site ( $-144 /-122)$ functions to maintain basal regulation of MUC5B in differentiated HBE cells and in HBE1 cells (Wu et al. 2007a). (Purple) NRG1 $\beta 1$ increases MUC5B gene expression in differentiated HBE cells by signaling through the ErbB2/ErbB3 heterodimer receptor, which then signals through three different pathways including p38, ERK1/2, and PI3k. PI3k goes on to activate Akt (Kettle et al. 2010). 
activated ERK1,2 pathway and also by ERK activation and secretion of CCL20. The latter mechanism activates the G-protein-coupled receptor CCR6, resulting in metalloprotease cleavage of EGFR pro-ligands and activation of MUC5AC gene expression. However, this is not a functional mechanism in primary differentiated HBE cells because they do not express CCR6 in vitro (Kim et al. 2011).

Neuregulin (NRG) 1 $\beta 1$, a member of the neuregulin growth factor family, binds to ERB2/ERB3 receptors, but not ERB4 or EGFR, in differentiated HBE cells, resulting in up-regulation of both the MUC5AC and MUC5B genes by activation of PI3K, p38, and Akt (Kettle et al. 2010). The activated transcription factors and cis-sites on the MUC5AC and MUC5B promoters to which they bind were not identified. Cigarette smoke also up-regulates expression of MUC5AC in $16 \mathrm{HBE}$ cells through the neuregulin $1 \beta / E R B 3$ pathway (Yu et al. 2011). In contrast, in differentiated HBE cells, cigarette smoke up-regulates monocyte chemotactic protein-1, which increases expression of both MUC5AC and $M U C 5 B$ genes via a cascade initiated by ligand/receptor (CCR2B) interactions and activation of PLC $\beta /$ PKC/MAPK (Monzon et al. 2011). $\mathrm{PGF}_{2 \alpha}$ binds to $\mathrm{FP}$, which couples to the Gq protein to activate $\mathrm{PKC}$, resulting in signaling through the MEK/ERK/RSK pathway and activation of CREB to induce MUC5AC expression in differentiated HBE cells (Chung et al. 2009). Double-stranded RNA (Zhu et al. 2009) and rhinovirus (RV) (Hewson et al. 2010) up-regulate MUC5AC expression in NCI-H292 cells through serially linked signaling cascades that result in activation of the EGFR-ERK pathway. This may reflect the exaggerated EGFR response in H292 cells (Kim et al. 2011) as RV up-regulates MUC5AC expression via a Src/MEK/NFкB pathway in primary tracheal cells (Inoue et al. 2006). Understanding how RV up-regulates secretory mucin gene expression may prove important in understanding the response of lung epithelial cells to virally induced exacerbations, which are clinically relevant in CF and asthma.

Bacterial products produced by the Gramnegative bacterium Pseudomonas aeruginosa predominate in CF airways and can directly me- diate lung mucin overproduction. $P$. aeruginosa lipopolysaccharide (LPS) was the first mediator shown to transcriptionally up-regulate expression of two secretory mucin genes-MUC2 ( $\mathrm{Li}$ et al. 1997) and MUC5AC ( Li et al. 1998) - in lung epithelial cells. Recently, the redox-active virulence factor pyocyanin produced by Pseudomonas PAO1 and other strains has been shown to increase MUC5AC and MUC2 mRNA and protein abundance in NCI-H292, but not in BEAS-2B, IB3-1, or 16BHE14o-, cells. PAO1 strains that express pyocyanin but lack genes that encode LPS, flagellum, or pilus increase MUC5AC and MUC2 mRNA levels (Rada et al. 2011), raising the possibility that commercial preparations of LPS used in earlier studies contained pyocyanin and that pyocyanin, rather than LPS or other bacterial components, is responsible for inducing MUC2 and MUC5AC gene expression during bacterial challenges. Pyocyanin-activated intracellular reactive oxygen species (ROS) and expression array analyses of NCI-H292 cells showed that it also induced expression of mediators potentially relevant to CF lung disease, including IL8, IL1 $\beta$, and TNF $\alpha$ (Rada et al. 2011). ROS production has also been shown to increase expression of MUC5AC mRNA and protein, as well as the pro-inflammatory mediators IL- 8 and IL1 $\beta$ (but not TNF $\alpha$ ), in NCI-H292 cells following exposure to Naegleria fowleri, an amoeboflagellate that invades the olfactory mucosa to access the central nervous system (Cervantes-Sandoval et al. 2009).

Neutrophils, the predominant inflammatory cells in CF airways, secrete neutrophil elastase, which was initially shown to increase MUC5AC gene expression both posttranscriptionally in A549 and differentiated HBE cells (Voynow et al. 1999) and transcriptionally in H292 cells (Kohri et al. 2002). Defensin human neutrophil peptide-1 (HNP-1), an antimicrobial peptide secreted by neutrophils and present at high concentrations in the airway fluid of CF patients, also increases levels of MUC5AC mRNA and protein in NCI-H292 cells, and like LPS, induces phosphorylation of ERK1/2 (Ishimoto et al. 2009).

Interleukin (IL) 17 cytokines and receptors are of considerable interest in CF because they 
S.M. Kreda et al.

modulate neutrophil recruitment to the lungs and host defense mechanisms against Gramnegative bacteria like Pseudomonas. IL17 cytokines are elevated in CF sputum (McAllister et al. 2005; Decraene et al. 2010) and in neutrophils in CF lungs (Brodlie et al. 2011). IL17 cytokines signal through IL17R, which is localized to basal cells in the differentiated HBE system (McAllister et al. 2005). Because IL17R is not expressed in secretory cells in the differentiated HBE system (McAllister et al. 2005), the mechanism whereby IL17 signaling is activated in secretory cells remains unclear. Nevertheless, IL17A increases MUC5AC (Fujisawa et al. 2009) and MUC5B (Fujisawa et al. 2011) gene expression in differentiated HBE cells through activation of $\mathrm{NF \kappa B}$ and binding of the NFKB subunit p50 at position - 3594/-3582 in the MUC5AC promoter and at 2921/-2909 in the MUC5B promoter. The Th2 cytokines IL4, IL9, and IL13 do not increase MUC5AC mRNA expression in CF sinus mucosal tissues following a $24-\mathrm{h}$ exposure, although they do increase expression of hCLCA1 (Hauber et al. 2010), a secretory granule membrane protein. These data support the concept that the TH2 cytokines IL4 and IL13 do not directly mediate MUC5AC mucin gene expression but, rather, impact the pathways that lead to formation of secretory granules in goblet cells, indirectly resulting in increased MUC5AC levels in respiratory tract tissues.

The CREB transcription factor is emerging as a major player in up-regulating MUC5AC gene expression (Fig. 4), which may have important clinical implications for the management of airway mucus overproduction in CF. There is a CRE cis-site ( $-878 /-871 \mathrm{nt})$ in the MUC5AC promoter and IL1 $\beta$ activates binding of CREB to that site in NCI-H292 and differentiated HNE cells (Song et al. 2003), as well as in A549 and differentiated HBE cells (YA Chen, AM Watson, LM Garvin, et al., unpubl.). In contrast, one study shows that HBE1 cells exposed to IL1 $\beta$ result in binding of the $\mathrm{NF \kappa B}$ subunit p50 to a NFKB cis-site $(-3594 /-3582 \mathrm{nt})$ in the MUC5AC promoter (Fujisawa et al. 2009). Binding of CREB to the CRE cis-site is also activated by the prostaglandins PGE2 (Gray et al. 2004) and $\mathrm{PGF}_{2 \alpha}$ (Chung et al. 2009) in NCI-
H292 and differentiated HBE cells. ATP exposure to NCI-H292 cells induces signal transduction pathways that activate CREB binding to the CRE site and also activate E26 transformationspecific (Ets) 1 binding to a nearby c-Ets1 site in the MUC5AC promoter (Song et al. 2008).

\section{Posttranscriptional Regulation of Secretory Mucin Genes}

Some mediators (acrolein, TNF $\alpha$, neutrophil elastase) regulate secretory mucin genes posttranscriptionally (for review, see Rose and Voynow 2006). IL8, which is present at high levels in CF airways, does not transcriptionally regulate secretory mucin gene expression but, rather, increases MUC5AC and MUC5B mRNA abundance in A549, H292, and differentiated HBE cells posttranscriptionally. IL8 increases the half-life of mucin transcripts and induces binding of RNA-binding proteins to specific sites in the $3^{\prime}$-untranslated sequence of MUC5AC (Bautista et al. 2009).

\section{Repression of MUC5AC Gene Expression}

Pharmacological agents like glucocorticoids and macrolides that are used to treat lung diseases also reduce mucin gene expression. Studies to investigate mechanisms, especially under conditions in which lung epithelial cells are exposed to inflammatory mediators, are underway in several laboratories. The glucocorticoid dexamethasone (Dex) transcriptionally represses MUC5AC gene expression following binding of Dex-activated GR to two GRE cis-sites on the MUC5AC promoter in A549 (Chen et al. 2006) and in differentiated HBE cells (Chen et al. 2012) and is mediated by histone deacetylase 2 (Chen et al. 2012).

The macrolide antibiotic azithromycin (AZT), which at low doses improves clinical outcome in CF patients, alters the gene profile of differentiated HBE cells by significantly increasing the expression of lipid/cholesterol genes and decreasing the expression of cell cycle/mitosis genes. Interestingly, AZT pre-treatment of cells exposed to inflammatory stimuli does not prevent up-regulation of most inflammatory 
mediators, but prevents up-regulation of the MUC5AC gene (Ribeiro et al. 2009), suggesting that AZT may directly impact expression of that mucin gene. In H292 cells, AZT and clarithromycin have inhibitory effects on MUC5AC mRNA levels induced by HNP-1 or lipopolysaccharide (LPS), whereas telithromycin, a semisynthetic erythromycin, has an inhibitory effect on MUC5AC production induced by LPS, but not by HNP-1. All three compounds have inhibitory effects on ERK1/2 phosphorylation induced by LPS, but not by HNP-1, indicating that these compounds interfere with different intracellular signal transduction pathways (Ishimoto et al. 2009).

\section{Summary: Mucin Gene Regulation}

The MUC5AC gene is typically expressed in goblet cells in the conducting airway epithelium, which are well positioned to respond to environmental and pathogenic airborne challenges. The MUC5B gene is typically expressed in glandular mucosal cells in healthy lungs and also in secretory cells in the conducting airway epithelium in diseases conditions. Both mucin genes are up-regulated by inflammatory mediators that impact diverse pathways and activate various transcription factors in lung epithelial cells. Although inroads into understanding the complexity of how MUC5AC gene expression is up-regulated and repressed, information on regulation of $M U C 5 B$ gene expression is more limited. Accumulating data show that regulation of both MUC5AC and MUC5B genes is modulated by diverse pathways in lung epithelial cells and that mechanisms in lung cancer cell lines, immortalized cells, and primary differentiated HBE cells are often, but not always, similar. Increased knowledge of the transcription factors and functional cis-sites in the $5^{\prime}$-flanking region and of the RNA-binding proteins and $3^{\prime}$-untranslated sites in polymeric MUC genes that are responsive to inflammatory mediators and to pharmacological agents will require additional studies to address their therapeutic impact. Further areas ripe for investigation include posttranscriptional and epigenetic regulation of mucin gene expression, as well as phar- macological modes of repressing mucin gene expression.

\section{Non-Infectious Inflammation Also Impacts Mucus Overproduction}

Inflammation is commonly thought of as being caused by infection and, as presented above, clearly impacts mucus overproduction. Other processes, for example, goblet cell and glandular hyperplasia, contribute to mucus overproduction (Rose and Voynow 2006). However, there are clearly non-infectious causes of mucus overproduction, as exemplified by the selective transgenic overexpression of $\beta E N a C$ in Clara cells in murine lungs using the CC10 promoter (Mall et al. 2004a; Zhou et al. 2011). Chronic inhibition of $\mathrm{Na}^{+}$in the mice by delivering amiloride in an aerosol blocks the mucus phenotype (Zhou et al. 2008), suggesting that it is not the overexpression of $\mathrm{ENaC}$, per se, that drives the inflammation. Although there are few signs of lung infection in $\beta E N a C$ Tg mice, some bacteria can be detected as expected because microbiome studies show a natural flora in the lungs. However, raising the mice in a germ-free (gnotobiotic), LPS-free facility yields mice with the same mucus plugging phenotype (Livraghi-Butrico et al. 2012). Hence, the inflammation and mucus metaplasia/overproduction appear to be caused by hyperabsorption of airway surface liquid and resulting concentration of the mucus gel rather than being secondary to bacterial infection. The implication of this observation is that the epithelium initiates an inflammatory attack against what it senses on the luminal surface as an abnormal mucus gel.

Notably, this hypothesis offers an explanation for the mucus meta/hyperplasia and plugging observed in many organs of CF patients that are not affected by bacterial infections (Quinton 2010). The cause of mucus plugging in many CF organs is uncertain, especially those that do not express ENaC and therefore do not experience the degree of dehydration that occurs in the airways (Donaldson and Boucher 2007; Bridges 2012). A hypothesis gaining widespread interest revolves around a deficiency in $\mathrm{HCO}_{3}^{-}$caused by functional impairment of 
S.M. Kreda et al.

mutated CFTR (Donaldson and Boucher 2007) and a resulting, profound failure of mucins to mature properly following their exocytic release, resulting in the formation of a dense, sticky mucus (Quinton 2010). This abnormal mucus is speculated then to trigger an inflammatory response in the epithelium, possibly similar to that occurring in the $\beta \mathrm{ENaC}$ Tg mouse.

\section{MUCIN BIOSYNTHESIS, GLYCOSYLATION, AND SECRETION}

\section{Overview}

The emerging paradigm with regard to $\mathrm{CF}$ and mucins, as presented above, is that CFTR is not expressed in goblet or mucosal cells and thus does not directly impact fundamental processes in mucin production and secretion. Nevertheless, mucins are clearly overproduced in CF and affect the morbidity and mortality of CF patients. Therefore, the current status of mucin biosynthesis, glycosylation, and secretion, as well as of mucus dynamics, and their contribution to CF diseases are reviewed below.

\section{Mucin Biosynthesis and Assembly}

Historically, mucin biosynthesis in intestinal goblet cells played an important role in unraveling the cell biology of protein synthesis and secretion; for example, the Golgi apparatus was originally identified as the site of protein glycosylation (Peterson and LeBlong 1964) using ${ }^{3} \mathrm{H}-$ glucose labeling of what we now know to be MUC2. Mucins are similar to other proteins and glycoproteins in their synthesis, contrasting mainly by virtue of their immense size and extensive glycosylation (for a recent review, see Thornton et al. 2007). They are secreted or localized to plasma membranes, thus their primary functions are centered on the extracellular environment, and their protein backbones are synthesized by ribosomes associated with the endoplasmic reticulum. The polymeric mucin proteins are dimerized in the endoplasmic reticulum lumen via their carboxy-terminal cysteine knot domains (Fig. 1A) (Dekker and Strous 1990; Bell et al. 2001). A specific protein disulfide isomerase, AGR2, has recently been shown to be essential for intestinal mouse Muc2 biosynthesis, because knockout of AGR2 leads to the loss of mucin secretion and colitis (Park et al. 2009). After transit to the Golgi apparatus, the mucin proteins (apomucins) are glycosylated, multimerized in the case of the polymeric species, and sorted at the trans-Golgi network into the regulated (polymeric mucins, MUC7) or constitutive (tethered mucins) limbs of the secretory pathway (see Davis and Dickey 2008). Recent studies with MUC5AC have revealed that GalNAc residues are transferred to serine and threonine residues in the MUC5AC apomucin in the Golgi and that stepwise synthesis and elongation of the final O-glycan structures are elaborated quickly in the HT-29 gastric cell line (Sheehan et al. 2004). Fully glycosylated lung mucins are filamentous (Rose et al. 1984), and mucin dimers of the polymeric mucins are on the order of $1 \mu \mathrm{m}$ in length, and $5 \mathrm{MDa}$ in molecular mass (Thornton et al. 2007). The importance of carboxy-terminal dimerization and amino-terminal multimerization of polymeric mucins was recognized with the sequencing of MUC2 and the identification, respectively, of the cystine knot and D domains, both having high homology to the respective domains of von Willebrand factor (vWF) (Gum et al. 1992; Desseyn et al. 2000). Present efforts on the assembly of polymeric mucins are using the recently revealed multimerization mechanism for vWF as a model (Huang et al. 2008). Given the scale of complexity and sizes of these massive molecules, the recent estimate for the full biosynthesis of a mucin polymer molecule in 2-4 h (Sheehan et al. 2004) is truly a remarkable feat of biology!

\section{Mucin Secretion and Regulation}

The sequence of signaling events regulating the exocytosis of mucin granules in goblet cells is complex and in a recent review (Davis and Dickey 2008) has been shown to share similarities with other secretory cells, for example, neurons, neuroendocrine cells, and pancreatic acinar cells (Burgoyne and Morgan 2003). Briefly, mucin granules are released via $\mathrm{Ca}^{2+}$ 
dependent exocytosis following interaction of an agonist with the goblet cell, with the best described secretagogues being ATP and UTP, agonists of the $\mathrm{P} 2 \mathrm{Y} 2$ receptor, coupled to $\mathrm{G} \alpha \mathrm{q} / 11$ and intracellular $\mathrm{Ca}^{2+}$ store mobilization (Kreda et al. 2007; Davis and Dickey 2008). However, other $\mathrm{Ca}^{2+}$-dependent agonists like serine proteases acting via protease-activated receptors have been recently identified as important mucin secretagogues in airway epithelia (Kreda et al. 2010). In the airways, cAMP-mediated agonists (e.g., isoproterenol) that activate CFTR do not stimulate mucin secretion from goblet cells (Davis and Dickey 2008), reinforcing the concept that the activation or inhibition of CFTR has no effect on mucin secretion (see Fig. 3) (Kreda et al. 2007), although cAMP does mediate mucin secretion in intestinal goblet cells (Bradbury 2000; Garcia et al. 2009). Interestingly, mucin secretagogues may also up-regulate mucin gene expression in vitro. For example, UTP, but not ATP, has been shown to up-regulate expression of the MUC5AC and MUC5B mucin genes in differentiated HBE cells (Chen et al. 2001b), but similar results have not been obtained in cancer cell lines. ATP has been reported to up-regulate MUC5AC gene expression in NCI-H292 cells in one study (Song et al. 2008), but another study showed that ATP does not increase MUC5AC protein levels in H292 cells (Rada et al. 2011). In differentiated HBE cells. neutrophil elastase functions both as a mucin secretagogue (Park et al. 2005) and an up-regulator of MUC5AC gene expression (Fischer and Voynow 2002; Voynow et al. 2004).

Recently, activations of the small G-protein RhoA and its downstream effector Rho kinase (ROCK) have been identified as critical steps in mucin granule exocytosis (Kreda et al. 2010). The main downstream effector of ROCK in airway goblet cells appears to be myosin light chain kinase (MLCK) (Seminario-Vidal et al. 2009; Kreda et al. 2010), which is essential in actomyosin cytoskeleton remodeling during mucin granule exocytosis (Davis and Dickey 2008; Kreda et al. 2010). However, other ROCK targets involved in agonist-stimulated granule secretion have been described; for example,
ROCK has been described to regulate MARCKS by phosphorylation (Sasaki 2003). MARCKS is also activated downstream from PKC and has been reported to regulate mucin granule exocytosis (Li et al. 2001; Singer et al. 2004).

The last steps of exocytosis are effected by the proteins that tether and dock the granule at the plasma membrane before exocytic fusion. The proteins that regulate this process have been well reviewed (Burgoyne and Morgan 2003; Davis and Dickey 2008). In regulated exocytosis of mucin granules, this interaction requires activation of Munc13 in a process termed "priming," by which Munc13 opens the conformation of the soluble NSF attachment protein (SNAP) receptors (SNAREs) to allow the assembly of the "core complex" or "SNARE core" (Davis and Dickey 2008). Genetic ablation of the Munc13-2 isoform in mice produces a defect in mucin secretion that is reflected, in part, by an accumulation of mucin granules within the goblet cells (Zhu et al. 2008). The SNARE complex, required for rapid fusion of the granule and cell membranes, is formed by the interaction of one R-SNARE, or VAMP (vesicle-associated membrane protein), and two or three Q-SNARES, whose identities in goblet cells remain undefined (Burgoyne and Morgan 2003; Davis and Dickey 2008). Syntaxins 2, 3, and 11 are candidate Q-SNARES for mucin granule exocytosis, and we have shown that syntaxin 3 is specifically localized apically in airway goblet cells (Kreda et al. 2007). Similarly, SNAP23 or SNAP25 has been postulated as the other Q-SNARE in the exocytotic core of mucin granules (Davis and Dickey 2008; Evans and Koo 2009), and deep-sequencing mRNA data showed that SNAP23, but not SNAP25, is highly expressed in airway epithelial cells (Jones et al. 2011). VAMP8 appears to be the R-SNARE in the exocytotic core of goblet cells because it is more than 10 times more highly expressed than other VAMPs in airway epithelial cells, and specific reduction of VAMP8 expression drastically decreases basal and agonist-mediated mucin granule exocytosis in airway goblet cells (Jones et al. 2011). Thus, a probable conformation of the mucin granule SNARE complex has VAMP8 in the granule membrane and SNAP23 and 
S.M. Kreda et al.

syntaxin 3 in the plasma membrane of airway goblet cells. The core complex activity is acutely regulated in response to second messengers $\mathrm{Ca}^{2+}$ and DAG, and the low-affinity, fast calcium-sensing synaptotagmin-2 is required for this activity in airway goblet cells as it is in neurons (Davis and Dickey 2008), because knockout of the isoform in mice produces a severe defect in ATP-induced mucin secretion in the airways (Tuvim et al. 2009).

Identification of other signaling components of the mucin secretory pathway (Davis and Dickey 2008) will be possible by genetic and pharmacological manipulations and highthroughput analysis of expression data, as well as high-resolution video-microscopy techniques. Importantly, some of these signaling components might be good targets for therapeutic inhibition of mucin hypersecretion in CF-affected organs, possibly as a prelude to intervention with anti-inflammatory or other therapeutic agents.

\section{Mucin Glycosylation and CF}

The O-glycans attached to serines and threonines in MUC protein backbones account for $50 \%-90 \%$ of the molecular mass of mucins (Fig. 1A,B). Historically, aberrant glycosylation of mucins in CF patients figured large before the cloning of CFTR in 1989, because there were several reports of higher levels of acidic mucins, along with increases in sulfation and either increases or decreases in the fucosylation and sialylation of mucins (Roussel et al. 1975; Chace et al. 1983; Cheng et al. 1989; also, for review, see Rose 1988; Rose and Voynow 2006). With the identification of CFTR and the suggestion that its effective absence from organelle and plasma membranes in CF cells was responsible for alkalization and dysfunction along the secretory pathway (Barasch et al. 1991; Barasch and alAwqati 1993), a possible mechanism was suggested. After many years of controversy, which led to increasingly sophisticated studies, the issue appears to have been resolved with the weight of the evidence indicating the physical absence of CFTR in the Golgi apparatus (see above), and no apparent role for CFTR in the maintenance of Golgi pH (Seksek et al. 1996; Gibson et al. 2000; Chandy et al. 2001; Haggie and Verkman 2009) or in the glycosylation of mucins and other glycoproteins (Jiang et al. 1997; Holmen et al. 2004; Leir et al. 2005). Biochemical analyses of $\mathrm{O}$-glycans indicate that changes in glycosylation of CF mucins appear to be a secondary effect of the disease that is largely due to inflammation (Davril et al. 1999; Roussel and Lamblin 2003; Schulz et al. 2007). Consistent with this notion, recent observations indicate that cytokines and other inflammatory mediators not only induce increases in mucin gene expression (as reviewed above) but also increase the expression of glycosyltransferases and sulfotransferases within the bronchial mucosa (Delmotte et al. 2002; Groux-Degroote et al. 2008). Possibly because of the large number and diversity of glycosyltransferases (Brockhausen et al. 2009), their roles in mucin synthesis and mucus biology are vastly underappreciated. The number of investigators in this field is small, but they are persistent, and a basic understanding of glycosyltransferase cell biology and physiology as it relates to mucin $\mathrm{O}$-glycosylation is gradually emerging (Ten Hagen et al. 2003; Cheng and Radhakrishnan 2011; Gerken et al. 2011). This information will impact our understanding of the molecular roles of $\mathrm{O}$-glycans in specific mucins and their functions in protecting the epithelium against pathogens in health and disease, including CF.

\section{Dynamics of Mucus Formation and Function}

The world of mucus is dynamic. These dynamics are perhaps most obvious in the airways, where beating cilia drive a sheet of mucus cephalad, continuously, as reported by Florey et al. (1932). Recent, closer observation by modern video-microscopy has revealed that polymeric mucins, MUC5B in particular, form strands and clumps that bind transiently to the tips of beating cilia and appear to be transported by being passed along from one ciliated cell to the next (Sears et al. 2011). These observations suggest a much closer and dynamic interaction between mucin molecules and ciliary surfaces 
than previously suspected, and imply transient molecular binding interactions forming between MUC5B and ciliary surfaces.

More subtly, mucus on mucosal surfaces is constantly being formed and degraded. Clara cells in the mouse airways do not react with periodic acid Schiff (PAS) stain, the archetypal mucin stain (Spicer et al. 1971). However, in the Munc13-2-null mouse, which has a defect in basal mucin secretion, the cells are $\mathrm{PAS}^{+}$, indicating an apparent accumulation that occurs as a result of hindered release of mucins (Zhu et al. 2008). Similarly, mucins are released continuously in the intestinal tract, forming the adherent mucus layer in the colon and stomach, then becoming part of the "floppy" layer as crosslinks responsible for the mesh-like arrangement in adherent layers are cleaved (Johansson et al. 2011; Ambort et al. 2012).

Even more subtly, mucus dynamics extends to the birth of mucins following their exocytic release from goblet and mucous cells. It has long been appreciated that mucins expand enormously as they hydrate following exocytic release from goblet cells, a process that was thought to be due to ionic repulsion of the fixed negative charges on mucin $O$-glycans, because $\mathrm{Ca}^{2+}$ packaged with the mucins was exchanged for $\mathrm{Na}^{+}$on the luminal surface (Verdugo 1991, 2012) A recent analysis of salivary MUC5B mucin implies an even more ordered packing of mucins in secretory granules than previously imagined. In these studies (Kesimer et al. 2009a), salivary MUC5B was subjected to density gradient centrifugation, which revealed three morphotypes of mucin by electron microscopy. One, a "compact form" that comprised $<10 \%$ of the total MUC5B in the sample, migrated to the bottom of the gradient. The polymer molecules had roughly circular profiles and cross-linked in such a way that the aminoand carboxy-terminal domains, arranged as nodes $\sim 10 \mathrm{~nm}$ in diameter, were in the central part of the complex, with the glycosylated domains of the mucin arrayed in the outer parts. Present in the middle of the gradient was a "moderately compact form," one in which the mucin appeared to be in the process of expanding from the compact form. And, at the top of the gradi- ent, representing the bulk of the total MUC5B, was the "linearized form," in which the mucins assumed open, linear, non-cross-linked confirmations. The hypothesis offered, presently under evaluation, is that the "compact form" represents a mucin molecule right after exocytic release into the luminal environment, and that it undergoes a maturation process, which may involve enzymatic cleavage, following which it assumes the "linearized form"; following this it is fully rendered into the mucus gel.

\section{CONCLUSIONS AND EMERGING DIRECTIONS}

The mechanism of mucin secretion in CF mucosal cells is normal and does not appear to be linked in any direct way to CFTR. Similarly, the mucus hyperproduction that typifies CF does not appear to be a direct cause of a defective CFTR, a major reason being the lack of CFTR expression in most mucin-secreting (goblet, mucous) cells. The overwhelming weight of the evidence reviewed above favors an indirect connection between CFTR expression and mucin overproduction in CF. The downstream consequences of mutant CFTR, for example, the lack of functional CFTR at the plasma membrane, clearly affect mucin overproduction in individuals with $\mathrm{CF}$ in ways that are not yet well understood. This is most apparent in CF lungs, where chronic inflammation and infection sustain conditions wherein mucin genes are up-regulated, resulting in increased production and secretion of polymeric mucins. Although recent studies from several laboratories have reinforced the concept that diverse stimuli modulate expression of the MUC5AC and MUC5B mucin genes in lung epithelial cells, regulation of these genes is complex. Additional studies are required for a full understanding of how these genes are modulated in CF and non-CF cells before therapeutic interventions can be maximized. In addition to inflammation that arises from infection, other pathways may stem from luminal environments gone awry. The $\beta E N a C$-overexpressing mouse mucus plugging phenotype is proving to be an archetypal example of this kind of inflammation, with a 
S.M. Kreda et al.

dehydrated airway surface/concentrated mucus gel apparently providing the inflammatory stimulus. We speculate that the luminal $\mathrm{HCO}_{3}^{-}$ deficiency presently being described for CF epithelia may also provide such a stimulus, by causing a mal-maturation of mucins as they are released onto luminal surfaces. The molecular mechanisms triggered by these stimuli have not been identified, but they are presently under study in multiple laboratories. Additionally, innate immune defense proteins secreted by lung cells that express CFTR may be altered in their levels or properties in CF patients as a direct consequence of CFTR, thereby contributing to the pathogenesis of CF lung diseases.

We continue to be amazed at the complex, pervasive pathways of dysfunction manifested in numerous cells and organs that result from gene defects in a single gene, CFTR, that underlies CF disease, especially mucosal epithelia. Thirty years ago, CF was thought to be a disease of mucus. Twenty years ago, the identification of CFTR as a $\mathrm{Cl}^{-}$channel caused the field to shift its attention dramatically away from mucus and mucins. Ten years ago, we began to appreciate that tertiary or higher-order effects of the defect in CFTR were driving mucus dysfunction and hyperproduction in CF. Finally, today, we may be approaching a full understanding of the train of molecular events that lead from mutations in CFTR to mucus overproduction, possibly via defects induced in the postsecretory maturation of mucins. In light of the numerous systems, organs, and tissues that are affected, CF is a systems biology disease, although it is the lungs that account for morbidity and mortality. Given the diversity of CFTR mutations, the challenge of circumventing airway mucus obstruction may be amenable in the future to a personalized-medicine approach to therapy.

\section{ACKNOWLEDGMENTS}

We are grateful to the CF and non-CF patient volunteers, globally, for tissue specimen donations, for the development of the knowledge expressed in this work would not have been possible without this material. Dr. Hiro Matsui kindly gave permission to use his images of concentrat- ed mucus (Fig. 1C), Dr. Lubna Abdulla graciously contributed the data shown in Figure 3A, and Lindsay Garvin, $\mathrm{PhD}$ candidate, generated Figures 4 and 5. This work is supported by several grants from the Cystic Fibrosis Foundation (to S.M.K., C.W.D., and M.C.R.); grants from Cystic Fibrosis Foundation Therapeutics (Davis 1997); the Mary Lynn Richardson Fund (to S.M.K.); and the National Institutes of Health grants HL34322 (to S.M.K.), HL34582 (to S.M.K.), HL51818 (to S.M.K.), HL34322 (Davis 1997), HL063756 (Davis 1997), HL60280 (Davis 1997), HL 97000 (Davis 1997), HL 33152 (to M.C.R.), and AI087717 (to M.C.R.).

\section{REFERENCES}

* Reference is also in this collection.

Abdullah LH, Conway JD, Cohn JA, Davis CW. 1997. Protein kinase $\mathrm{C}$ and $\mathrm{Ca}^{2+}$ activation of mucin secretion in airway goblet cells. Am J Physiol 273: L201L210.

Abdullah LH, Wolber C, Kesimer M, Sheehan JK, Davis CW. 2012. Studying mucin secretion from human bronchial epithelial cell primary cultures. Methods Mol Biol 842: 259-277.

Ajonuma LC, Ng EH, Chow PH, Hung CY, Tsang LL, Cheung AN, Brito-Jones C, Lok IH, Haines J, Chan HC. 2005. Increased cystic fibrosis transmembrane conductance regulator (CFTR) expression in the human hydrosalpinx. Hum Reprod 20: 1228-1234.

Allen A, Hutton DA, Pearson JP, Sellers LA. 1984. Mucus glycoprotein structure, gel formation and gastrointestinal mucus function. Ciba Found Symp 109: 137156.

* Ambort D, Johansson MEV, Gustafsson JK, Ermund A, Hansson GC. 2012. Perspectives on mucus properties and formation-lessons from the biochemical world. Cold Spring Harb Perspect Med doi: 10.1101/cshperspect .a014159.

Andersch-Bjorkman Y, Thomsson KA, Holmen Larsson JM, Ekerhovd E, Hansson GC. 2007. Large scale identification of proteins, mucins, and their $\mathrm{O}$-glycosylation in the endocervical mucus during the menstrual cycle. Mol Cell Proteomics 6: 708-716.

Anderson DH. 1938. Cystic fibrosis of the pancreas and its relation to celiac disease: A clinical and pathological study. Am J Dis Child 56: 344-399.

Ballard ST, Inglis SK. 2004. Liquid secretion properties of airway submucosal glands. J Physiol 556: 1-10.

Ballard ST, Spadafora D. 2007. Fluid secretion by submucosal glands of the tracheobronchial airways. Respir Physiol Neurobiol 159: 271-277.

Barasch J, al-Awqati Q. 1993. Defective acidification of the biosynthetic pathway in cystic fibrosis. J Cell Sci Suppl 17: $229-233$. 
Barasch J, Kiss B, Prince A, Saiman L, Gruenert D, al-Awqati Q. 1991. Defective acidification of intracellular organelles in cystic fibrosis. Nature 352: 70-73.

Bautista MV, Chen Y, Ivanova VS, Rahimi MK, Watson AM, Rose MC. 2009. IL-8 regulates mucin gene expression at the posttranscriptional level in lung epithelial cells. J Immunol 183: 2159-2166.

Bell SL, Xu G, Forstner JF. 2001. Role of the cystine-knot motif at the C-terminus of rat mucin protein Muc2 in dimer formation and secretion. Biochem J 357: 203-209.

Best JA, Quinton PM. 2005. Salivary secretion assay for drug efficacy for cystic fibrosis in mice. Exp Physiol 90: 189193.

Boat TF, Cheng PW, Wood RE. 1976. Tracheobronchial mucus secretion in vivo and in vitro by epithelial tissues from cystic fibrosis and control subjects. Mod Probl Paediatr 19: $141-152$.

Boat TF, Welsh MJ, Beaudet AL. 1989. Cystic fibrosis. In The metabolic basis of inherited disease (ed. Scriver CR, et al.), pp. 2649-2680. McGraw-Hill, New York.

Boucher RC. 2007. Cystic fibrosis: A disease of vulnerability to airway surface dehydration. Trends Mol Med 13: $231-$ 240.

Bove PF, Grubb BR, Okada SF, Ribeiro CM, Rogers TD, Randell SH, O'Neal WK, Boucher RC. 2010. Human alveolar type II cells secrete and absorb liquid in response to local nucleotide signaling. J Biol Chem 285: 3493934949.

Bradbury NA. 2000. Protein kinase-A-mediated secretion of mucin from human colonic epithelial cells. J Cell Physiol 185: $408-415$.

Brezillon S, Dupuit F, Hinnrasky J, Marchand V, Kalin N, Tummler B, Puchelle E. 1995. Decreased expression of the CFTR protein in remodeled human nasal epithelium from non-cystic fibrosis patients. Lab Invest 72: 191-200.

* Bridges RJ. 2012. Mechanisms of bicarbonate secretion: Lessons from the airways. Cold Spring Harb Perspect Med doi: 10.1101/cshperspect.a015016.

Brochiero E, Dagenais A, Prive A, Berthiaume Y, Grygorczyk R. 2004. Evidence of a functional CFTR $\mathrm{Cl}^{-}$channel in adult alveolar epithelial cells. Am J Physiol Lung Cell Mol Physiol 287: L382-L392.

Brockhausen I, Schachter H, Stanley P. 2009. O-GalNAc glycans. In Essentials of glycobiology, 2nd ed. (ed. Varki A, et al.), Chapter 9. Cold Spring Harbor Laboratory Press, Cold Spring Harbor, NY.

Brodlie M, McKean MC, Johnson GE, Anderson AE, Hilkens CM, Fisher AJ, Corris PA, Lordan JL, Ward C. 2011. Raised interleukin-17 is immunolocalised to neutrophils in cystic fibrosis lung disease. Eur Respir J 37: 1378-1385.

Brugman SM, Taussig LM. 1984. The reproductive system. In Cystic fibrosis (ed. Taussig LM), pp. 323-337. ThiemeStratton, New York.

Bruscia E, Sangiuolo F, Sinibaldi P, Goncz KK, Novelli G, Gruenert DC. 2002. Isolation of CF cell lines corrected at $\Delta$ F508-CFTR locus by SFHR-mediated targeting. Gene Ther 9: 683-685.

Bruscia EM, Zhang PX, Ferreira E, Caputo C, Emerson JW, Tuck D, Krause DS, Egan ME. 2009. Macrophages directly contribute to the exaggerated inflammatory response in cystic fibrosis transmembrane conductance regulator $^{-1-}$ mice. Am J Respir Cell Mol Biol 40: $295-$ 304.

Burgoyne RD, Morgan A. 2003. Secretory granule exocytosis. Physiol Rev 83: 581-632.

Caramori G, Casolari P, Di GC, Saetta M, Baraldo S, Boschetto P, Ito K, Fabbri LM, Barnes PJ, Adcock IM, et al. 2009. MUC5AC expression is increased in bronchial submucosal glands of stable COPD patients. Histopathology 55: 321-331.

Carvalho-Oliveira I, Efthymiadou A, Malho R, Nogueira P, Tzetis M, Kanavakis E, Amaral MD, Penque D. 2004. CFTR localization in native airway cells and cell lines expressing wild-type or F508del-CFTR by a panel of different antibodies. J Histochem Cytochem 52: 193-203.

Castagna I, Roszkowska AM, Fama F, Sinicropi S, Ferreri G. 2001. The eye in cystic fibrosis. Eur J Ophthalmol 11: 9-14.

Cervantes-Sandoval I, Serrano-Luna JJ, Meza-Cervantez P, Arroyo R, Tsutsumi V, Shibayama M. 2009. Naegleria fowleri induces MUC5AC and pro-inflammatory cytokines in human epithelial cells via ROS production and EGFR activation. Microbiology 155: 3739-3747.

Chace KV, Leahy DS, Martin R, Carubelli R, Flux M, Sachdev GP. 1983. Respiratory mucous secretions in patients with cystic fibrosis: Relationship between levels of highly sulfated mucin component and severity of the disease. Clin Chim Acta 132: 143-155.

Chan HC, Ruan YC, He Q, Chen MH, Chen H, Xu WM, Chen WY, Xie C, Zhang XH, Zhou Z. 2009. The cystic fibrosis transmembrane conductance regulator in reproductive health and disease. J Physiol 587: 2187-2195.

Chandy G, Grabe M, Moore HP, Machen TE. 2001. Proton leak and CFTR in regulation of Golgi pH in respiratory epithelial cells. Am J Physiol Cell Physiol 281: C908-C921.

Chen Y, Zhao YH, Di YP, Wu R. 2001a. Characterization of human mucin $5 \mathrm{~B}$ gene expression in airway epithelium and the genomic clone of the amino-terminal and $5^{\prime}$ flanking region. Am J Respir Cell Mol Biol 25: 542-553.

Chen Y, Zhao YH, Wu R. 2001b. Differential regulation of airway mucin gene expression and mucin secretion by extracellular nucleotide triphosphates. Am J Respir Cell Mol Biol 25: 409-417.

Chen Y, Nickola TJ, DiFronzo NL, Colberg-Poley AM, Rose MC. 2006. Dexamethasone-mediated repression of MUC5AC gene expression in human lung epithelial cells. Am J Respir Cell Mol Biol 34: 338-347.

Chen G, Korfhagen TR, Xu Y, Kitzmiller J, Wert SE, Maeda Y, Gregorieff A, Clevers H, Whitsett JA. 2009. SPDEF is required for mouse pulmonary goblet cell differentiation and regulates a network of genes associated with mucus production. J Clin Invest 119: 2914-2924.

Chen EY, Yang N, Quinton PM, Chin WC. 2010. A new role for bicarbonate in mucus formation. Am J Physiol Lung Cell Mol Physiol 299: L542-L549.

Chen YA, Watson AM, Williamson CD, Rahimi MK, Liang C, Colberg-Poley AM, Rose MC. 2012. Glucocorticoid receptor and HDAC2 mediate the dexamethasone-induced repression of the MUC5AC gene (submitted).

Cheng PW, Radhakrishnan P. 2011. Mucin O-glycan branching enzymes: Structure, function, and gene regulation Adv Exp Med Biol 705: 465-492. 
S.M. Kreda et al.

Cheng PW, Boat TF, Cranfill K, Yankaskas JR, Boucher RC. 1989. Increased sulfation of glycoconjugates by cultured nasal epithelial cells from patients with cystic fibrosis J Clin Invest 84: 68-72.

Cheng SH, Gregory RJ, Marshall J, Paul S, Souza DW, White GA, O’Riordan CR, Smith AE. 1990. Defective intracellular transport and processing of CFTR is the molecular basis of most cystic fibrosis. Cell 63: 827-834.

Childers M, Eckel G, Himmel A, Caldwell J. 2007. A new model of cystic fibrosis pathology: Lack of transport of glutathione and its thiocyanate conjugates. Med Hypotheses 68: $101-112$.

Choi JY, Khansaheb M, Joo NS, Krouse ME, Robbins RC, Weill D, Wine JJ. 2009. Substance P stimulates human airway submucosal gland secretion mainly via a CFTRdependent process. J Clin Invest 119: 1189-1200.

Cholon DM, O’Neal WK, Randell SH, Riordan JR, Gentzsch M. 2010. Modulation of endocytic trafficking and apical stability of CFTR in primary human airway epithelial cultures. Am J Physiol Lung Cell Mol Physiol 298: L304L314.

Chung WC, Ryu SH, Sun H, Zeldin DC, Koo JS. 2009. CREB mediates prostaglandin $\mathrm{F} 2 \alpha$-induced MUC5AC overexpression. J Immunol 182: 2349-2356.

Claass A, Sommer M, de JH, Kalin N, Tummler B. 2000 Applicability of different antibodies for immunohistochemical localization of CFTR in sweat glands from healthy controls and from patients with cystic fibrosis. J Histochem Cytochem 48: 831-837.

Cohn JA, Melhus O, Page LJ, Dittrich KL, Vigna SR. 1991. CFTR: Development of high-affinity antibodies and localization in sweat gland. Biochem Biophys Res Commun 181: $36-43$.

Cohn JA, Strong TV, Picciotto MR, Nairn AC, Collins FS, Fitz JG. 1993. Localization of the cystic fibrosis transmembrane conductance regulator in human bile duct epithelial cells. Gastroenterology 105: 1857-1864.

Cone RA. 2009. Barrier properties of mucus. Adv Drug Deliv Rev 61: 75-85.

Corfield AP, Myerscough N, Longman R, Sylvester P, Arul S, Pignatelli M. 2000. Mucins and mucosal protection in the gastrointestinal tract: New prospects for mucins in the pathology of gastrointestinal disease. Gut 47: 589-594.

Crawford I, Maloney PC, Zeitlin PL, Guggino WB, Hyde SC, Turley H, Gatter KC, Harris A, Higgins CF. 1991. Immunocytochemical localization of the cystic fibrosis gene product CFTR. Proc Natl Acad Sci 88: 9262-9266.

Davies JR, Svitacheva N, Lannefors L, Kornfalt R, Carlstedt I. 1999. Identification of MUC5B, MUC5AC and small amounts of MUC2 mucins in cystic fibrosis airway secretions. Biochem J 344: 321-330.

Davies WL, Vandenberg JI, Sayeed RA, Trezise AE. 2004 Cardiac expression of the cystic fibrosis transmembrane conductance regulator involves novel exon 1 usage to produce a unique amino-terminal protein. J Biol Chem 279: $15877-15887$.

Davis CW. 1997. Goblet cells: Physiology and pharmacology. In Airway mucus: Basic mechanisms and clinical perspectives (ed. Rogers DF, Lethem MI), pp. 150-177. Berkhauser, Basel, Switzerland.
Davis CW, Dickey BF. 2008. Regulated airway goblet cell mucin secretion. Annu Rev Physiol 70: 487-512.

Davril M, Degroote S, Humbert P, Galabert C, Dumur V, Lafitte JJ, Lamblin G, Roussel P. 1999. The sialylation of bronchial mucins secreted by patients suffering from cystic fibrosis or from chronic bronchitis is related to the severity of airway infection. Glycobiology 9: 311-321.

Decraene A, Willems-Widyastuti A, Kasran A, De Boeck K, Bullens DM, Dupont LJ. 2010. Elevated expression of both mRNA and protein levels of IL-17A in sputum of stable cystic fibrosis patients. Respir Res 11: 177.

Dekker J, Strous GJ. 1990. Covalent oligomerization of rat gastric mucin occurs in the rough endoplasmic reticulum, is $N$-glycosylation-dependent, and precedes initial O-glycosylation. J Biol Chem 265: 18116-18122.

Delmotte P, Degroote S, Lafitte JJ, Lamblin G, Perini JM, Roussel P. 2002. Tumor necrosis factor $\alpha$ increases the expression of glycosyltransferases and sulfotransferases responsible for the biosynthesis of sialylated and/or sulfated Lewis $\mathrm{x}$ epitopes in the human bronchial mucosa. J Biol Chem 277: 424-431.

Desseyn JL, Aubert JP, Porchet N, Laine A. 2000. Evolution of the large secreted gel-forming mucins. Mol Biol Evol 17: $1175-1184$.

Donaldson SH, Boucher RC. 2007. Sodium channels and cystic fibrosis. Chest 132: 1631-1636.

Dorfman R, Nalpathamkalam T, Taylor C, Gonska T, Keenan K, Yuan XW, Corey M, Tsui LC, Zielenski J, Durie P. 2010. Do common in silico tools predict the clinical consequences of amino-acid substitutions in the CFTR gene? Clin Genet 77: 464-473.

Dray-Charier N, Paul A, Veissiere D, Mergey M, Scoazec JY, Capeau J, Brahimi-Horn C, Housset C. 1995. Expression of cystic fibrosis transmembrane conductance regulator in human gallbladder epithelial cells. Lab Invest 73: $828-836$.

Duchatel F, Muller F, Oury JF, Mennesson B, Boue J, Boue A. 1993. Prenatal diagnosis of cystic fibrosis: Ultrasonography of the gallbladder at 17-19 weeks of gestation. Fetal Diagn Ther 8: 28-36.

Dupuit F, Kalin N, Brezillon S, Hinnrasky J, Tummler B, Puchelle E. 1995. CFTR and differentiation markers expression in non-CF and $\Delta \mathrm{F} 508$ homozygous CF nasal epithelium. J Clin Invest 96: 1601-1611.

Engelhardt JF, Yankaskas JR, Ernst SA, Yang Y, Marino CR, Boucher RC, Cohn JA, Wilson JM. 1992. Submucosal glands are the predominant site of CFTR expression in the human bronchus. Nat Genet 2: 240-248.

Engelhardt JF, Zepeda M, Cohn JA, Yankaskas JR, Wilson JM. 1994. Expression of the cystic fibrosis gene in adult human lung. J Clin Invest 93: 737-749.

Enhorning G, Huldt L, Melen B. 1970. Ability of cervical mucus to act as a barrier against bacteria. Am J Obstet Gynecol 108: 532-537.

Evans CM, Koo JS. 2009. Airway mucus: The good, the bad, the sticky. Pharmacol Ther 121: 332-348.

Farber S, Shwachman H, Maddock CL. 1943. Pancreatic function and disease in early life. I. Pancreatic enzyme activity and the celiac syndrome. J Clin Invest 22: $827-$ 838. 
Fischer BM, Voynow JA. 2002. Neutrophil elastase induces $M U C 5 A C$ gene expression in airway epithelium via a pathway involving reactive oxygen species. Am J Respir Cell Mol Biol 26: 447-452.

Florey H. 1930. The secretion of mucus by the colon. $\mathrm{Br} \mathrm{J}$ Exp Pathol 11: 348-361.

Florey H, Carleton HM, Wells AQ. 1932. Mucus secretion in the trachea. Br J Exp Pathol 13: 269-284.

Forte TM, Forte JG. 1970. Histochemical staining and characterization of glycoproteins in acid-secreting cells of frog stomach. J Cell Biol 47: 437-452.

Freudenberg F, Leonard MR, Liu SA, Glickman JN, Carey MC. 2010. Pathophysiological preconditions promoting mixed "black" pigment plus cholesterol gallstones in a $\Delta$ F508 mouse model of cystic fibrosis. Am J Physiol Gastrointest Liver Physiol 299: G205-G214.

Fujisawa T, Velichko S, Thai P, Hung LY, Huang F, Wu R. 2009. Regulation of airway MUC5AC expression by IL-1 $\beta$ and IL-17A; the NF- $\mathrm{B}$ paradigm. I Immunol 183: 6236-6243.

Fujisawa T, Chang MM, Velichko S, Thai P, Hung LY, Huang F, Phuong N, Chen Y, Wu R. 2011. NF-кB mediates IL$1 \beta$ - and IL-17A-induced MUC5B expression in airway epithelial cells. Am J Respir Cell Mol Biol 45: 246-252.

Garcia MA, Yang N, Quinton PM. 2009. Normal mouse intestinal mucus release requires cystic fibrosis transmembrane regulator-dependent bicarbonate secretion. J Clin Invest 119: 2613-2622.

Gerken TA, Jamison O, Perrine CL, Collette JC, Moinova H, Ravi L, Markowitz SD, Shen W, Patel H, Tabak LA. 2011. Emerging paradigms for the initiation of mucin-type protein $\mathrm{O}$-glycosylation by the polypeptide GalNAc transferase family of glycosyltransferases. $J$ Biol Chem 286: 14493-14507.

Gibson GA, Hill WG, Weisz OA. 2000. Evidence against the acidification hypothesis in cystic fibrosis. Am J Physiol Cell Physiol 279: C1088-C1099.

Goldsworthy NE, Florey H. 1930. Some properties of mucus, with special reference to its antibacterial functions. Br J Exp Pathol 11: 192-208.

Gouyer V, Leir SH, Tetaert D, Liu Y, Gottrand F, Harris A, Desseyn JL. 2010. The characterization of the first antimouse Muc6 antibody shows an increased expression of the mucin in pancreatic tissue of Cftr-knockout mice. Histochem Cell Biol 133: 517-525.

Govindarajan B, Gipson IK. 2010. Membrane-tethered mucins have multiple functions on the ocular surface. Exp Eye Res 90: 655-663.

Gray T, Nettesheim P, Loftin C, Koo JS, Bonner J, Peddada S, Langenbach R. 2004. Interleukin-1 $\beta$-induced mucin production in human airway epithelium is mediated by cyclooxygenase-2, prostaglandin E2 receptors, and cyclic AMP-protein kinase A signaling. Mol Pharmacol 66: $337-346$.

Groux-Degroote S, Krzewinski-Recchi MA, Cazet A, Vincent A, Lehoux S, Lafitte JJ, Van S, Delannoy P. 2008. IL-6 and IL-8 increase the expression of glycosyltransferases and sulfotransferases involved in the biosynthesis of sialylated and/or sulfated Lewis $\mathrm{x}$ epitopes in the human bronchial mucosa. Biochem J 410: 213-223.
Gruenert DC, Finkbeiner WE, Widdicombe JH. 1995. Culture and transformation of human airway epithelial cells. Am J Physiol 268: L347-L360.

Gum JRJr, Hicks JW, Toribara NW, Rothe EM, Lagace RE, Kim YS. 1992. The human MUC2 intestinal mucin has cysteine-rich subdomains located both upstream and downstream of its central repetitive region. J Biol Chem 267: 21375-21383.

Guo X, Pace RG, Stonebraker JR, Commander CW, Dang AT, Drumm ML, Harris A, Zou F, Swallow DM, Wright FA, et al. 2011. Mucin variable number tandem repeat polymorphisms and severity of cystic fibrosis lung disease: Significant association with MUC5AC. PLoS ONE 6: e25452.

Haggie PM, Verkman AS. 2009. Defective organellar acidification as a cause of cystic fibrosis lung disease: Reexamination of a recurring hypothesis. Am J Physiol Lung Cell Mol Physiol 296: L859-L867.

Hattrup CL, Gendler SJ. 2008. Structure and function of the cell surface (tethered) mucins. Annu Rev Physiol 70: 431-457.

Hauber HP, Lavigne F, Hung HL, Levitt RC, Hamid Q. 2010. Effect of Th2 type cytokines on hCLCA1 and mucus expression in cystic fibrosis airways. J Cyst Fibros 9: 277-279.

Hays SR, Fahy JV. 2006. Characterizing mucous cell remodeling in cystic fibrosis: Relationship to neutrophils. Am J Respir Crit Care Med 174: 1018-1024.

Henke MO, Renner A, Huber RM, Seeds MC, Rubin BK. 2004. MUC5AC and MUC5B mucins are decreased in cystic fibrosis airway secretions. Am J Respir Cell Mol Biol 31: 86-91.

Henke MO, John G, Germann M, Lindemann H, Rubin BK. 2007. MUC5AC and MUC5B mucins increase in cystic fibrosis airway secretions during pulmonary exacerbation. Am J Respir Crit Care Med 175: 816-821.

Henke MO, John G, Rheineck C, Chillappagari S, Naehrlich L, Rubin BK. 2011. Serine proteases degrade airway mucins in cystic fibrosis. Infect Immun 79: 3438-3444.

Hewson CA, Edbrooke MR, Johnston SL. 2004. PMA induces the MUC5AC respiratory mucin in human bronchial epithelial cells, via PKC, EGF/TGF- $\alpha$, Ras/Raf, MEK, ERK and Sp1-dependent mechanisms. J Mol Biol 344: 683-695.

Hewson CA, Haas JJ, Bartlett NW, Message SD, Laza-Stanca V, Kebadze T, Caramori G, Zhu J, Edbrooke MR, Stanciu LA, et al. 2010. Rhinovirus induces MUC5AC in a human infection model and in vitro via NF- $\mathrm{\kappa B}$ and EGFR pathways. Eur Respir J 36: 1425-1435.

Hihnala S, Kujala M, Toppari J, Kere J, Holmberg C, Hoglund P. 2006. Expression of SLC26A3, CFTR and NHE3 in the human male reproductive tract: Role in male subfertility caused by congenital chloride diarrhoea. Mol Hum Reprod 12: 107-111.

Hodges CA, Drumm ML. 2009. CF: Tissue by tissue. Pediatr Pulmonol 32: 188-189.

Hodges CA, Palmert MR, Drumm ML. 2008. Infertility in females with cystic fibrosis is multifactorial: Evidence from mouse models. Endocrinology 149: 2790-2797.

Hollingsworth MA. 1999. Proteins expressed by pancreatic duct cells and their relatives. Ann NY Acad Sci 880: $38-49$. 
S.M. Kreda et al.

Hollingsworth MA, Swanson BJ. 2004. Mucins in cancer Protection and control of the cell surface. Nat Rev Cancer 4: 45-60.

Holmen JM, Karlsson NG, Abdullah LH, Randell SH, Sheehan JK, Hansson GC, Davis CW. 2004. Mucins and their $O$-glycans from human bronchial epithelial cell cultures. Am J Physiol Lung Cell Mol Physiol 287: L824-L834

Hovenberg HW, Davies JR, Carlstedt I. 1996a. Different mucins are produced by the surface epithelium and the submucosa in human trachea: Identification of MUC5AC as a major mucin from the goblet cells. Biochem J 318: 319-324.

Hovenberg HW, Davies JR, Herrmann A, Linden CJ, Carlstedt I. 1996b. MUC5AC, but not MUC2, is a prominent mucin in respiratory secretions. Glycoconj J 13: 839-847.

Huang RH, Wang Y, Roth R, Yu X, Purvis AR, Heuser JE, Egelman EH, Sadler JE. 2008. Assembly of Weibel-Palade body-like tubules from $\mathrm{N}$-terminal domains of von Willebrand factor. Proc Natl Acad Sci 105: 482-487.

Inoue $\mathrm{D}$, Yamaya $\mathrm{M}$, Kubo $\mathrm{H}$, Sasaki T, Hosoda M, Numasaki M, Tomioka Y, Yasuda H, Sekizawa K, Nishimura H, et al. 2006. Mechanisms of mucin production by rhinovirus infection in cultured human airway epithelial cells. Respir Physiol Neurobiol 154: 484-499.

Ishimoto H, Mukae H, Sakamoto N, Amenomori M, Kitazaki T, Imamura Y, Fujita H, Ishii H, Nakayama S, Yanagihara K, et al. 2009. Different effects of telithromycin on MUC5AC production induced by human neutrophil peptide-1 or lipopolysaccharide in NCI-H292 cells compared with azithromycin and clarithromycin. J Antimicrob Chemother 63: 109-114.

Jacquot J, Puchelle E, Hinnrasky J, Fuchey C, Bettinger C, Spilmont C, Bonnet N, Dieterle A, Dreyer D, Pavirani A. 1993. Localization of the cystic fibrosis transmembrane conductance regulator in airway secretory glands. Eur Respir J 6: 169-176.

Jakab RL, Collaco AM, Ameen NA. 2011. Physiological relevance of cell-specific distribution patterns of CFTR NKCC1, NBCe1, and NHE3 along the crypt-villus axis in the intestine. Am J Physiol Gastrointest Liver Physiol 300: G82-G98.

Jiang X, Hill WG, Pilewski JM, Weisz OA. 1997. Glycosylation differences between a cystic fibrosis and rescued airway cell line are not CFTR dependent. Am J Physiol 273: L913-L920.

Johansson ME, Gustafsson JK, Sjoberg KE, Petersson J, Holm L, Sjovall H, Hansson GC. 2010. Bacteria penetrate the inner mucus layer before inflammation in the dextran sulfate colitis model. PLoS ONE 5: e12238.

Johansson ME, Ambort D, Pelaseyed T, Schutte A, Gustafsson JK, Ermund A, Subramani DB, Holmen-Larsson JM Thomsson KA, Bergstrom JH, et al. 2011. Composition and functional role of the mucus layers in the intestine. Cell Mol Life Sci 68: 3635-3641.

Jones LC, Moussa L, Fulcher LM, Zhu Y, Hudson EJ, O’Neal WK, Randell SH, Lazarowski ER, Boucher RC, Kreda SM 2011. VAMP8 is a vesicle SNARE that regulates mucin secretion in airway goblet cells. J Physiol 590: 545-562.

Joo NS, Irokawa T, Wu JV, Robbins RC, Whyte RI, Wine JJ. 2002. Absent secretion to vasoactive intestinal peptide in cystic fibrosis airway glands. J Biol Chem 277: 5071050715.
Jouret F, Devuyst O. 2009. CFTR and defective endocytosis: New insights in the renal phenotype of cystic fibrosis. Pflugers Arch 457: 1227-1236.

Kalin N, Claass A, Sommer M, Puchelle E, Tummler B. 1999. $\Delta$ F508 CFTR protein expression in tissues from patients with cystic fibrosis. J Clin Invest 103: 1379-1389.

Kartner N, Augustinas O, Jensen TJ, Naismith AL, Riordan JR. 1992. Mislocalization of $\Delta$ F508 CFTR in cystic fibrosis sweat gland. Nat Genet 1: 321-327.

Kesimer M, Kirkham S, Pickles RJ, Henderson AS, Alexis NE, DeMaria G, Knight D, Thornton DJ, Sheehan JK. 2008. Tracheobronchial air-liquid interface cell culture: A model for innate mucosal defense of the upper airways? Am J Physiol Lung Cell Mol Physiol 296: L92-L100.

Kesimer M, Makhov AM, Griffith JD, Verdugo P, Sheehan JK. 2009a. Unpacking a gel forming mucin: A view of MUC5B organization after granular release. Am J Physiol Lung Cell Mol Physiol 298: L15-L22.

Kettle R, Simmons J, Schindler F, Jones P, Dicker T, Dubois G, Giddings J, Van HG, Jones CE. 2010. Regulation of neuregulin $1 \beta 1$-induced MUC5AC and MUC5B expression in human airway epithelium. Am J Respir Cell Mol Biol 42: 472-481.

Kim KC, Hisatsune A, Kim DJ, Miyata T. 2003. Pharmacology of airway goblet cell mucin release. J Pharmacol Sci 92: 301-307.

Kim S, Lewis C, Nadel JA. 2011. CCL20/CCR6 feedback exaggerates epidermal growth factor receptor-dependent MUC5AC mucin production in human airway epithelial (NCI-H292) cells. J Immunol 186: 3392-3400.

Kirkham S, Sheehan JK, Knight D, Richardson PS, Thornton DJ. 2002. Heterogeneity of airways mucus: Variations in the amounts and glycoforms of the major oligomeric mucins MUC5AC and MUC5B. Biochem J 361: 537-546.

Klymiuk N, Mundhenk L, Kraehe K, Wuensch A, Plog S, Emrich D, Langenmayer MC, Stehr M, Holzinger A, Kroner C, et al. 2011. Sequential targeting of CFTR by BAC vectors generates a novel pig model of cystic fibrosis. J Mol Med (Berl) 90: 597-608.

Knowles MR, Boucher RC. 2002. Mucus clearance as a primary innate defense mechanism for mammalian airways. J Clin Invest 109: 571-577.

Kohri K, Ueki IF, Nadel JA. 2002. Neutrophil elastase induces mucin production by ligand-dependent epidermal growth factor receptor activation. Am J Physiol Lung Cell Mol Physiol 283: L531-L540.

Kondo M, Finkbeiner WE, Widdicombe JH. 1993. Cultures of bovine tracheal epithelium with differentiated ultrastructure and ion transport. In Vitro Cell Dev Biol 29A: $19-24$.

Kreda SM, Gentzsch M. 2011. Imaging CFTR protein localization in cultured cells and tissues. Methods Mol Biol 742: $15-33$.

Kreda SM, Mall M, Mengos A, Rochelle L, Yankaskas J, Riordan JR, Boucher RC. 2005. Characterization of wild-type and $\Delta \mathrm{F} 508$ cystic fibrosis transmembrane regulator in human respiratory epithelia. Mol Biol Cell 16: 2154-2167.

Kreda SM, Okada SF, van Heusden CA, O’Neal W, Gabriel S, Abdullah L, Davis CW, Boucher RC, Lazarowski ER 2007. Coordinated release of nucleotides and mucin 
from human airway epithelial Calu-3 cells. J Physiol 584: 245-259.

Kreda SM, Seminario-Vidal L, van Heusden CA, O’Neal W, Jones L, Boucher RC, Lazarowski ER. 2010. Receptorpromoted exocytosis of airway epithelial mucin granules containing a spectrum of adenine nucleotides. J Physiol 588: $2255-2267$

Kujala M, Hihnala S, Tienari J, Kaunisto K, Hastbacka J, Holmberg C, Kere J, Hoglund P. 2007. Expression of ion transport-associated proteins in human efferent and epididymal ducts. Reproduction 133: 775-784.

Kuver R, Klinkspoor JH, Osborne WR, Lee SP. 2000. Mucous granule exocytosis and CFTR expression in gallbladder epithelium. Glycobiology 10: 149-157.

Leir SH, Parry S, Palmai-Pallag T, Evans J, Morris HR, Dell A, Harris A. 2005. Mucin glycosylation and sulphation in airway epithelial cells is not influenced by cystic fibrosis transmembrane conductance regulator expression. Am $J$ Respir Cell Mol Biol 32: 453-461.

Lemjabbar H, Basbaum C. 2002. Platelet-activating factor receptor and ADAM10 mediate responses to Staphylococcus aureus in epithelial cells. Nat Med 8: 41-46.

Lethem MI, Dowell ML, Van Scott M, Yankaskas JR, Egan T, Boucher RC, Davis CW. 1993. Nucleotide regulation of goblet cells in human airway epithelial explants: Normal exocytosis in cystic fibrosis. Am J Respir Cell Mol Biol 9: 315-322.

Li JD, Dohrman AF, Gallup M, Miyata S, Gum JR, Kim YS, Nadel JA, Prince A, Basbaum CB. 1997. Transcriptional activation of mucin by Pseudomonas aeruginosa lipopolysaccharide in the pathogenesis of cystic fibrosis lung disease. Proc Natl Acad Sci 94: 967-972.

Li D, Gallup M, Fan N, Szymkowski DE, Basbaum CB. 1998. Cloning of the amino-terminal and $5^{\prime}$-flanking region of the human MUC5AC mucin gene and transcriptional upregulation by bacterial exoproducts. J Biol Chem 273: 6812-6820.

Li Y, Martin LD, Spizz G, Adler KB. 2001. MARCKS protein is a key molecule regulating mucin secretion by human airway epithelial cells in vitro. J Biol Chem 276: $40982-$ 40990.

Linden SK, Sutton P, Karlsson NG, Korolik V, McGuckin MA. 2008. Mucins in the mucosal barrier to infection. Mucosal Immunol 1: 183-197.

Litt M, Khan MA, Chakrin LW, Wardell JR Jr, Christian P. 1974. The viscoelasticity of fractionated canine tracheal mucus. Biorheology 11: 111-117.

Livraghi A, Grubb BR, Hudson EJ, Wilkinson KJ, Sheehan JK, Mall MA, O’Neal WK, Boucher RC, Randell SH 2009. Airway and lung pathology due to mucosal surface dehydration in $\beta$-epithelial $\mathrm{Na}^{+}$channel-overexpressing mice: Role of TNF- $\alpha$ and IL- 4 R $\alpha$ signaling, influence of neonatal development, and limited efficacy of glucocorticoid treatment. J Immunol 182: 4357-4367.

Livraghi-Butrico A, Kelly EJ, Klem ER, Dang H, Wolfgang MC, Boucher RC, Randell SH, O’Neal WK. 2012. Mucus clearance and MyD88-dependent immunity modulate lung susceptibility to spontaneous bacterial infection and inflammation. Mucosal Immunol doi: 10.1038/ mi.2012.17.

Mall M, Grubb BR, Harkema JR, O’Neal WK, Boucher RC. 2004a. Increased airway epithelial $\mathrm{Na}^{+}$absorption pro- duces cystic fibrosis-like lung disease in mice. Nat Med 10: $487-493$.

Mall M, Kreda SM, Mengos A, Jensen TJ, Hirtz S, Seydewitz HH, Yankaskas J, Kunzelmann K, Riordan JR, Boucher RC. 2004b. The $\Delta$ F508 mutation results in loss of CFTR function and mature protein in native human colon. Gastroenterology 126: 32-41.

Manson AL, Trezise AE, MacVinish LJ, Kasschau KD, Birchall N, Episkopou V, Vassaux G, Evans MJ, Colledge WH, Cuthbert AW, et al. 1997. Complementation of null CF mice with a human CFTR YAC transgene. EMBO J 16: $4238-4249$.

Marino CR, Matovcik LM, Gorelick FA, Cohn JA. 1991. Localization of the cystic fibrosis transmembrane conductance regulator in pancreas. J Clin Invest 88: 712-716.

Martinez-Anton A, Debolos C, Garrido M, Roca-Ferrer J, Barranco C, Alobid I, Xaubet A, Picado C, Mullol J. 2006. Mucin genes have different expression patterns in healthy and diseased upper airway mucosa. Clin Exp Allergy 36: 448-457.

Matsui H, Grubb BR, Tarran R, Randell SH, Gatzy JT, Davis CW, Boucher RC. 1998. Evidence for periciliary liquid layer depletion, not abnormal ion composition, in the pathogenesis of cystic fibrosis airways disease. Cell 95: 1005-1015.

Matsui H, Verghese MW, Kesimer M, Schwab UE, Randell SH, Sheehan JK, Grubb BR, Boucher RC. 2005. Reduced three-dimensional motility in dehydrated airway mucus prevents neutrophil capture and killing bacteria on airway epithelial surfaces. J Immunol 175: 1090-1099.

McAllister F, Henry A, Kreindler JL, Dubin PJ, Ulrich L, Steele C, Finder JD, Pilewski JM, Carreno BM, Goldman SJ, et al. 2005. Role of IL-17A, IL-17F, and the IL-17 receptor in regulating growth-related oncogene- $\alpha$ and granulocyte colony-stimulating factor in bronchial epithelium: Implications for airway inflammation in cystic fibrosis. J Immunol 175: 404-412.

Meyerholz DK, Stoltz DA, Namati E, Ramachandran S, Pezzulo AA, Smith AR, Rector MV, Suter MJ, Kao S, McLennan G, et al. 2010. Loss of cystic fibrosis transmembrane conductance regulator function produces abnormalities in tracheal development in neonatal pigs and young children. Am J Respir Crit Care Med 182: 12511261.

Monzon ME, Forteza RM, Casalino-Matsuda SM. 2011. MCP-1/CCR2B-dependent loop upregulates MUC5AC and MUC5B in human airway epithelium. Am J Physiol Lung Cell Mol Physiol 300: L204-L215.

Moskwa P, Lorentzen D, Excoffon KJ, Zabner J, McCray PB Jr, Nauseef MW, Dupuy C, Banfi B. 2007. A novel host defense system of airways is defective in cystic fibrosis. Am J Respir Crit Care Med 175: 174-183.

Mulberg AE, Weyler RT, Altschuler SM, Hyde TM. 1998. Cystic fibrosis transmembrane conductance regulator expression in human hypothalamus. Neuroreport 9: 141144.

Park RW, Grand RJ. 1981. Gastrointestinal manifestations of cystic fibrosis: A review. Gastroenterology 81: 1143-1161.

Park JA, He F, Martin LD, Li Y, Chorley BN, Adler KB. 2005. Human neutrophil elastase induces hypersecretion of mucin from well-differentiated human bronchial 
S.M. Kreda et al.

epithelial cells in vitro via a protein kinase $\mathrm{C} \delta$-mediated mechanism. Am J Pathol 167: 651-661.

Park SW, Zhen G, Verhaeghe C, Nakagami Y, Nguyenvu LT, Barczak AJ, Killeen N, Erle DJ. 2009. The protein disulfide isomerase AGR2 is essential for production of intestinal mucus. Proc Natl Acad Sci 106: 6950-6955.

Parmley RR, Gendler SJ. 1998. Cystic fibrosis mice lacking Mucl have reduced amounts of intestinal mucus. J Clin Invest 102: 1798-1806.

Penque D, Mendes F, Beck S, Farinha C, Pacheco P, Nogueira P, Lavinha J, Malho R, Amaral MD. 2000. Cystic fibrosis F508del patients have apically localized CFTR in a reduced number of airway cells. Lab Invest 80: 857-868.

Peterson M, Leblond CP. 1964. Synthesis of complex carbohydrates in the Golgi region, as shown by radioautography after injection of labeled glucose. J Cell Biol 21: 143-148.

Pickles RJ. 2004. Physical and biological barriers to viral vector-mediated delivery of genes to the airway epithelium. Proc Am Thorac Soc 1: 302-308.

Puchelle E, Gaillard D, Ploton D, Hinnrasky J, Fuchey C, Boutterin MC, Jacquot J, Dreyer D, Pavirani A, Dalemans W. 1992. Differential localization of the cystic fibrosis transmembrane conductance regulator in normal and cystic fibrosis airway epithelium. Am J Respir Cell Mol Biol 7: 485-491.

Quinton PM. 1983. Chloride impermeability in cystic fibrosis. Nature 301: 421-422.

Quinton PM. 1990. Cystic fibrosis: A disease in electrolyte transport. FASEB J 4: 2709-2717.

Quinton PM. 2010. Role of epithelial $\mathrm{HCO}_{3}$ transport in mucin secretion: Lessons from cystic fibrosis. Am J Physiol Cell Physiol 299: C1222-C1233.

Rada B, Gardina P, Myers TG, Leto TL. 2011. Reactive oxygen species mediate inflammatory cytokine release and EGFR-dependent mucin secretion in airway epithelial cells exposed to Pseudomonas pyocyanin. Mucosal Immunol 4: 158-171.

Reid CJ, Gould S, Harris A. 1997a. Developmental expression of mucin genes in the human respiratory tract. Am J Respir Cell Mol Biol 17: 592-598.

Reid CJ, Hyde K, Ho SB, Harris A. 1997b. Cystic fibrosis of the pancreas: Involvement of MUC6 mucin in obstruction of pancreatic ducts. Mol Med 3: 403-411.

Rhodes JM. 1989. Colonic mucus and mucosal glycoproteins: The key to colitis and cancer? Gut 30: 1660-1666.

Ribeiro CM, Hurd H, Wu Y, Martino ME, Jones L, Brighton B, Boucher RC, O’Neal WK. 2009. Azithromycin treatment alters gene expression in inflammatory, lipid metabolism, and cell cycle pathways in well-differentiated human airway epithelia. PLoS ONE 4: e5806.

* Riordan JR. 2012. Cold Spring Harb Perspect Med (to be published).

Robert R, Thoreau V, Norez C, Cantereau A, Kitzis A, Mettey Y, Rogier C, Becq F. 2004. Regulation of the cystic fibrosis transmembrane conductance regulator channel by $\beta$-adrenergic agonists and vasoactive intestinal peptide in rat smooth muscle cells and its role in vasorelaxation. J Biol Chem 279: 21160-21168.
Rochwerger L, Buchwald M. 1993. Stimulation of the cystic fibrosis transmembrane regulator expression by estrogen in vivo. Endocrinology 133: 921-930.

Rogan MP, Taggart CC, Greene CM, Murphy PG, O’Neill SJ, McElvaney NG. 2004. Loss of microbicidal activity and increased formation of biofilm due to decreased lactoferrin activity in patients with cystic fibrosis. J Infect Dis 190: 1245-1253.

Rogers CS, Stoltz DA, Meyerholz DK, Ostedgaard LS, Rokhlina T, Taft PF, Rogan MP, Pezzulo AA, Karp PH, Itani OA, et al. 2008. Disruption of the CFTR gene produces a model of cystic fibrosis in newborn pigs. Science 321: 1837-1841.

Rose MC. 1988. Epithelial mucous glycoproteins and cystic fibrosis. Horm Metab Res 20: 601-608.

Rose MC. 2006. Mucus. In Encyclopedia of respiratory medicine (ed. Laurent GJ, Shapiro SJ), pp. 62-66. Academic Press, San Diego.

Rose MC, Voynow JA. 2006. Respiratory tract mucin genes and mucin glycoproteins in health and disease. Physiol Rev 86: 245-278.

Rose MC, Lynn WS, Kaufman B. 1979. Resolution of the major components of human lung mucosal gel and their capabilities for reaggregation and gel formation. Biochemistry 18: 4030-4037.

Rose MC, Voter WA, Brown CF, Kaufman B. 1984. Structural features of human tracheobronchial mucus glycoprotein Biochem J 222: 371-377.

Rose MC, Brown CF, Jacoby JZ III, Lynn WS, Kaufman B. 1987. Biochemical properties of tracheobronchial mucins from cystic fibrosis and non-cystic fibrosis individuals. Pediatr Res 22: 545-551.

Rousseau K, Kirkham S, Johnson L, Fitzpatrick B, Howard M, Adams EJ, Rogers DF, Knight D, Clegg P, Thornton DJ. 2008. Proteomic analysis of polymeric salivary mucins: No evidence for MUC19 in human saliva. Biochem J 413: 545-552.

Roussel P, Lamblin G. 2003. The glycosylation of airway mucins in cystic fibrosis and its relationship with lung infection by Pseudomonas aeruginosa. Adv Exp Med Biol 535: $17-32$.

Roussel P, Lamblin G, Degand P. 1975. Heterogeneity of the carbohydrate chains of sulfated bronchial glycoproteins isolated from a patient suffering from cystic fibrosis. J Biol Chem 250: 2114-2122.

Roy MG, Rahmani M, Hernandez JR, Alexander SN, Ehre C, Ho SB, Evans CM. 2011. Mucin production during prenatal and postnatal murine lung development. Am J Respir Cell Mol Biol 44: 755-760.

Sasaki Y. 2003. New aspects of neurotransmitter release and exocytosis: Rho-kinase-dependent myristoylated alanine-rich C-kinase substrate phosphorylation and regulation of neurofilament structure in neuronal cells. J Pharmacol Sci 93: 35-40.

Sasaki M, Ikeda H, Nakanuma Y. 2007. Expression profiles of MUC mucins and trefoil factor family (TFF) peptides in the intrahepatic biliary system: Physiological distribution and pathological significance. Prog Histochem Cytochem 42: 61-110.

Schachter H, Dixon GH. 1965. A comparative study of the proteins in normal meconium and in meconium from 
meconium ileus patients. Can J Biochem Physiol 43: 381397.

Schulz BL, Sloane AJ, Robinson LJ, Prasad SS, Lindner RA, Robinson M, Bye PT, Nielson DW, Harry JL, Packer NH, et al. 2007. Glycosylation of sputum mucins is altered in cystic fibrosis patients. Glycobiology 17: 698-712.

Sears PR, Davis CW, Chua M, Sheehan JK. 2011. Mucociliary interactions and mucus dynamics in ciliated human bronchial epithelial cell cultures. Am J Physiol Lung Cell Mol Physiol 301: L181-L186.

Seksek O, Biwersi J, Verkman AS. 1996. Evidence against defective trans-Golgi acidification in cystic fibrosis. J Biol Chem 271: 15542-15548.

Seminario-Vidal L, Kreda S, Jones L, O’Neal W, Trejo J, Boucher RC, Lazarowski ER. 2009. Thrombin promotes release of ATP from lung epithelial cells through coordinated activation of rho- and $\mathrm{Ca}^{2+}$-dependent signaling pathways. J Biol Chem 284: 20638-20648.

Sheehan JK, Kirkham S, Howard M, Woodman P, Kutay S, Brazeau C, Buckley J, Thornton DJ. 2004. Identification of molecular intermediates in the assembly pathway of the MUC5AC mucin. J Biol Chem 279: 15698-15705.

Shen BQ, Finkbeiner WE, Wine JJ, Mrsny RJ, Widdicombe JH. 1994. Calu-3: A human airway epithelial cell line that shows cAMP-dependent $\mathrm{Cl}^{-}$secretion. Am J Physiol 266: L493-L501.

Singer M, Martin LD, Vargaftig BB, Park J, Gruber AD, Li Y, Adler LB. 2004. A MARCKS-related peptide blocks mucus hypersecretion in a mouse model of asthma. Nat Med 10: 193-196.

Smith JJ, Travis SM, Greenberg EP, Welsh MJ. 1996. Cystic fibrosis airway epithelia fail to kill bacteria because of abnormal airway surface fluid. Cell 85: 229-236.

Snouwaert JN, Brigman KK, Latour AM, Malouf NN, Boucher RC, Smithies O, Koller BH. 1992. An animal model for cystic fibrosis made by gene targeting. Science 257: $1083-1088$.

Song KS, Lee WJ, Chung KC, Koo JS, Yang EJ, Choi JY, Yoon JH. 2003. Interleukin- $1 \beta$ and tumor necrosis factor- $\alpha$ induce MUC5AC overexpression through a mechanism involving ERK/p38 mitogen-activated protein kinasesMSK1-CREB activation in human airway epithelial cells. J Biol Chem 278: 23243-23250.

Song KS, Lee TJ, Kim K, Chung KC, Yoon JH. 2008. cAMPresponding element-binding protein and c-Ets1 interact in the regulation of ATP-dependent MUC5AC gene expression. J Biol Chem 283: 26869-26878.

Spicer SS, Chakrin LW, Wardell JR Jr, Kendrick W. 1971. Histochemistry of mucosubstances in the canine and human respiratory tract. Lab Invest 25: 483-490.

Spurr-Michaud S, Argueso P, Gipson I. 2007. Assay of mucins in human tear fluid. Exp Eye Res 84: 939-950.

Strong TV, Boehm K, Collins FS. 1994. Localization of cystic fibrosis transmembrane conductance regulator mRNA in the human gastrointestinal tract by in situ hybridization. J Clin Invest 93: 347-354.

Sturgess J. 1982. Morphological characteristics of the bronchial mucosa in cystic fibrosis. In Fluid and electrolyte abnormalities in exocrine glands in cystic fibrosis (ed. Quinton PM, et al.), pp. 254-270. San Francisco Press, San Francisco.
Sturgess J, Imrie J. 1982. Quantitative evaluation of the development of tracheal submucosal glands in infants with cystic fibrosis and control infants. Am J Pathol 106: 303-311.

Sun X, Sui H, Fisher JT, Yan Z, Liu X, Cho HJ, Joo NS, Zhang Y, Zhou W, Yi Y, et al. 2010. Disease phenotype of a ferret CFTR-knockout model of cystic fibrosis. JClin Invest 120: 3149-3160.

Takeyama K, Dabbagh K, Lee HM, Agusti C, Lausier JA, Ueki IF, Grattan KM, Nadel JA. 1999. Epidermal growth factor system regulates mucin production in airways. Proc Natl Acad Sci 96: 3081-3086.

Taylor C, Allen A, Dettmar PW, Pearson JP. 2004. Two rheologically different gastric mucus secretions with different putative functions. Biochim Biophys Acta 1674: 131-138.

Ten Hagen KG, Fritz TA, Tabak LA. 2003. All in the family: The UDP-GalNAc:polypeptide $N$-acetylgalactosaminyltransferases. Glycobiology 13: 1R-16R.

Thai P, Loukoianov A, Wachi S, Wu R. 2008. Regulation of airway mucin gene expression. Annu Rev Physiol 70: 405-429.

* Thomas P, Lukacs G. 2012. Cold Spring Harb Perspect Med (to be published).

Thornton DJ, Rousseau K, McGuckin MA. 2007. Structure and function of the polymeric mucins in airways mucus. Annu Rev Physiol 70: 459-486.

Tirouvanziam R, Khazaal I, Peault B. 2002. Primary inflammation in human cystic fibrosis small airways. Am J Physiol Lung Cell Mol Physiol 283: L445-L451.

Tizzano EF, Buchwald M. 1995. CFTR expression and organ damage in cystic fibrosis. Ann Intern Med 123: 305-308.

Tizzano EF, Chitayat D, Buchwald M. 1993. Cell-specific localization of CFTR mRNA shows developmentally regulated expression in human fetal tissues. Hum Mol Genet 2: 219-224.

Tizzano EF, O'Brodovich H, Chitayat D, Benichou JC, Buchwald M. 1994a. Regional expression of CFTR in developing human respiratory tissues. Am J Respir Cell Mol Biol 10: $355-362$.

Tizzano EF, Silver MM, Chitayat D, Benichou JC, Buchwald M. 1994b. Differential cellular expression of cystic fibrosis transmembrane regulator in human reproductive tissues. Clues for the infertility in patients with cystic fibrosis. Am J Pathol 144: 906-914.

Trapnell BC, Chu CS, Paakko PK, Banks TC, Yoshimura K, Ferrans VJ, Chernick MS, Crystal RG. 1991. Expression of the cystic fibrosis transmembrane conductance regulator gene in the respiratory tract of normal individuals and individuals with cystic fibrosis. Proc Natl Acad Sci 88: 6565-6569.

Trezise AE, Buchwald M. 1991. In vivo cell-specific expression of the cystic fibrosis transmembrane conductance regulator. Nature 353: 434-437.

Trezise AE, Chambers JA, Wardle CJ, Gould S, Harris A. 1993. Expression of the cystic fibrosis gene in human foetal tissues. Hum Mol Genet 2: 213-218.

Tuvim MJ, Mospan AR, Burns KA, Chua M, Mohler PJ, Melicoff E, Adachi R, Ammar-Aouchiche Z, Davis CW Dickey BF. 2009. Synaptotagmin 2 couples mucin granule 
S.M. Kreda et al.

exocytosis to $\mathrm{Ca}^{2+}$ signaling from endoplasmic reticulum. J Biol Chem 284: 9781-9787.

Verdugo P. 1991. Mucin exocytosis. Am Rev Respir Dis 144: S33-S37.

* Verdugo P. 2012. Supramolecular dynamics of mucus. Cold Spring Harb Perspect Med doi: 10.1101/cshperspect.a009597.

Voynow JA, Rubin BK. 2009. Mucins, mucus, and sputum. Chest 135: 505-512.

Voynow JA, Young LR, Wang Y, Horger T, Rose MC, Fischer BM. 1999. Neutrophil elastase increases MUC5AC mRNA and protein expression in respiratory epithelial cells. Am J Physiol 276: L835-L843.

Voynow JA, Fischer BM, Malarkey DE, Burch LH, Wong T, Longphre M, Ho SB, Foster WM. 2004. Neutrophil elastase induces mucus cell metaplasia in mouse lung. Am J Physiol Lung Cell Mol Physiol 287: L1293-L1302.

Voynow JA, Fischer BM, Roberts BC, Proia AD. 2005. Basallike cells constitute the proliferating cell population in cystic fibrosis airways. Am J Respir Crit Care Med 172: 1013-1018.

Welsh MJ, Tsui L-C, Boat TF, Beaudet AL. 1995. Cystic fibrosis. In The metabolic basis of inherited disease, 4 th ed. (ed. Scriver CR, et al.), pp. 3799-3876. McGraw-Hill, New York.

Wine JJ, Joo NS. 2004. Submucosal glands and airway defense. Proc Am Thorac Soc 1: 47-53.

Wine JJ, Joo NS, Choi JY, Cho HJ, Krouse ME, Wu JV, Khansaheb M, Irokawa T, Ianowski J, Hanrahan JW, et al. 2011. Measurement of fluid secretion from intact airway submucosal glands. Methods Mol Biol 742: 93-112.

Wu R, Yankaskas J, Cheng E, Knowles MR, Boucher RC 1985. Growth and differentiation of human nasal epithelial cells in culture: Serum-free, hormone-supplemented medium and proteoglycan synthesis. Am Rev Respir Dis 132: 311-320.

Wu R, Martin WR, Robinson CB, St George JA, Plopper CG, Kurland G, Last JA, Cross CE, McDonald RJ, Boucher R. 1990. Expression of mucin synthesis and secretion in human tracheobronchial epithelial cells grown in culture. Am J Respir Cell Mol Biol 3: 467-478.

Wu DY, Wu R, Chen Y, Tarasova N, Chang MM. 2007a. PMA stimulates MUC5B gene expression through an Sp1based mechanism in airway epithelial cells. Am J Respir Cell Mol Biol 37: 589-597.

Wu JV, Krouse ME, Wine JJ. 2007b. Acinar origin of CFTRdependent airway submucosal gland fluid secretion. Am J Physiol Lung Cell Mol Physiol 292: L304-L311.

Xia B, Royall JA, Damera G, Sachdev GP, Cummings RD. 2005. Altered $O$-glycosylation and sulfation of airway mucins associated with cystic fibrosis. Glycobiology 15: $747-775$.

Xu WM, Shi QX, Chen WY, Zhou CX, Ni Y, Rowlands DK, Yi LG, Zhu H, Ma ZG, Wang XF, et al. 2007. Cystic fibrosis transmembrane conductance regulator is vital to sperm fertilizing capacity and male fertility. Proc Natl Acad Sci 104: 9816-9821.

Yang Y, Raper SE, Cohn JA, Engelhardt JF, Wilson JM. 1993. An approach for treating the hepatobiliary disease of cys- tic fibrosis by somatic gene transfer. Proc Natl Acad Sci 90 4601-4605.

Yankaskas JR, Haizlip JE, Conrad M, Koval D, Lazarowski E, Paradiso AM, Rinehart CA Jr, Sarkadi B, Schlegel R, Boucher RC. 1993. Papilloma virus immortalized tracheal epithelial cells retain a well-differentiated phenotype. Am J Physiol 264: C1219-C1230.

Yoshimura K, Nakamura H, Trapnell BC, Chu CS, Dalemans W, Pavirani A, Lecocq JP, Crystal RG. 1991. Expression of the cystic fibrosis transmembrane conductance regulator gene in cells of non-epithelial origin. Nucleic Acids Res 19: 5417-5423.

Yu H, Li Q, Kolosov VP, Perelman JM, Zhou X. 2011. Regulation of cigarette smoke-induced mucin expression by neuregulin1 $\beta /$ ErbB3 signalling in human airway epithelial cells. Basic Clin Pharmacol Toxicol 109: 63-72.

Yuan-Chen WD, Wu R, Reddy SP, Lee YC, Chang MM. 2007. Distinctive epidermal growth factor receptor/extracellular regulated kinase-independent and -dependent signaling pathways in the induction of airway mucin $5 \mathrm{~B}$ and mucin 5AC expression by Phorbol 12-Myristate 13-Acetate. Am J Pathol 170: 20-32.

Zabner J, Smith JJ, Karp PH, Widdicombe JH, Welsh MJ. 1998. Loss of CFTR chloride channels alters salt absorption by cystic fibrosis airway epithelia in vitro. Mol Cell 2: 397-403.

Zalewska A, Zwierz K, Zolkowski K, Gindzienski A. 2000. Structure and biosynthesis of human salivary mucins. Acta Biochim Pol 47: 1067-1079.

Zeng W, Lee MG, Yan M, Diaz J, Benjamin I, Marino CR, Kopito R, Freedman S, Cotton C, Muallem S, et al. 1997. Immuno and functional characterization of CFTR in submandibular and pancreatic acinar and duct cells. Am J Physiol 273: C442-C455.

Zhang Y, Doranz B, Yankaskas JR, Engelhardt JF. 1995. Genotypic analysis of respiratory mucous sulfation defects in cystic fibrosis. J Clin Invest 96: 2997-3004.

Zhou Z, Treis D, Schubert SC, Harm M, Schatterny J, Hirtz S, Duerr J, Boucher RC, Mall MA. 2008. Preventive but not late amiloride therapy reduces morbidity and mortality of lung disease in $\beta \mathrm{ENaC}$-overexpressing mice. $\mathrm{Am}$ J Respir Crit Care Med 178: 1245-1256.

Zhou Z, Duerr J, Johannesson B, Schubert SC, Treis D, Harm M, Graeber SY, Dalpke A, Schultz C, Mall MA 2011. The ENaC-overexpressing mouse as a model of cystic fibrosis lung disease. J Cyst Fibros 10: S172-S182.

Zhu Y, Ehre C, Abdullah LH, Sheehan JK, Roy M, Evans CM, Dickey BF, Davis CW. 2008. MUNC13-2 $2^{-/-}$baseline secretion defect reveals source of oligomeric mucins in mouse airways. J Physiol 586: 1977-1992.

Zhu L, Lee PK, Lee WM, Zhao Y, Yu D, Chen Y. 2009. Rhinovirus-induced major airway mucin production involves a novel TLR3-EGFR-dependent pathway. Am J Respir Cell Mol Biol 40: 610-619.

Zuelzer WW, Newton WA Jr. 1949. The pathogenesis of fibrocystic disease of the pancreas; a study of 36 cases with special reference to the pulmonary lesions. Pediatrics 4: 53-69.

Zuhdi Alimam M, Piazza FM, Selby DM, Letwin N, Huang L, Rose MC. 2000. Muc-5/5ac mucin messenger RNA and protein expression is a marker of goblet cell metaplasia in murine airways. Am J Respir Cell Mol Biol 22: 253-260. 


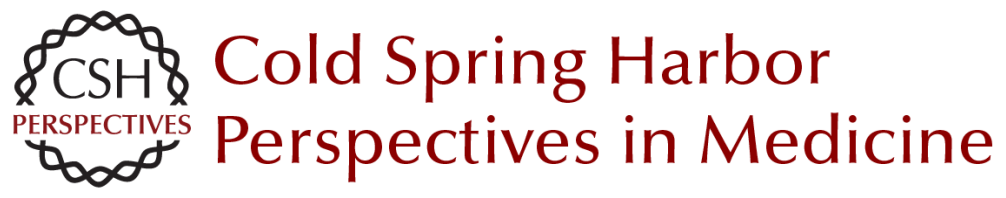

\section{CFTR, Mucins, and Mucus Obstruction in Cystic Fibrosis}

Silvia M. Kreda, C. William Davis and Mary Callaghan Rose

Cold Spring Harb Perspect Med 2012; doi: 10.1101/cshperspect.a009589

Subject Collection Cystic Fibrosis

Antibiotic and Anti-Inflammatory Therapies for Cystic Fibrosis James F. Chmiel, Michael W. Konstan and J. Stuart Elborn

Structure and Function of the Mucus Clearance System of the Lung Brenda M. Button and Brian Button

New Pulmonary Therapies Directed at Targets Other than CFTR

Scott H. Donaldson and Luis Galietta

The Cystic Fibrosis Airway Microbiome

Susan V. Lynch and Kenneth D. Bruce

Cystic Fibrosis Transmembrane Conductance

Regulator (ABCC7) Structure

John F. Hunt, Chi Wang and Robert C. Ford

Status of Fluid and Electrolyte Absorption in

Cystic Fibrosis

M.M. Reddy and M. Jackson Stutts

The Influence of Genetics on Cystic Fibrosis

Phenotypes

Michael R. Knowles and Mitchell Drumm

Perspectives on Mucus Properties and Formation

--Lessons from the Biochemical World

Daniel Ambort, Malin E.V. Johansson, Jenny K.

Gustafsson, et al.
The Cystic Fibrosis Intestine

Robert C. De Lisle and Drucy Borowitz

Cystic Fibrosis Transmembrane Regulator

Correctors and Potentiators

Steven M. Rowe and Alan S. Verkman

The Cystic Fibrosis of Exocrine Pancreas

Michael Wilschanski and Ivana Novak

Dynamics Intrinsic to Cystic Fibrosis

Transmembrane Conductance Regulator Function and Stability

P. Andrew Chong, Pradeep Kota, Nikolay V.

Dokholyan, et al.

The Cystic Fibrosis Gene: A Molecular Genetic

Perspective

Lap-Chee Tsui and Ruslan Dorfman

The CFTR Ion Channel: Gating, Regulation, and

Anion Permeation

Tzyh-Chang Hwang and Kevin L. Kirk

Assessing the Disease-Liability of Mutations in CFTR

Claude Ferec and Garry R. Cutting

Supramolecular Dynamics of Mucus Pedro Verdugo

For additional articles in this collection, see http://perspectivesinmedicine.cshlp.org/cgi/collection/ 